MICHAE GOCHNA

https://orcid.org/0000-0001-7765-2240

Instytut Historii im. T. Manteuffla Polskiej Akademii Nauk w Warszawie

TOMASZ ZWIĄZEK

https://orcid.org/0000-0002-5798-8203

Instytut Historii im. T. Manteuffla Polskiej Akademii Nauk w Warszawie

\title{
SPATIO-TEMPORAL ASPECTS \\ OF THE EXTRAORDINARY TAX COLLECTING SYSTEM IN GREATER POLAND (1492-1613)
}

Zarys treści: W artykule omawiane są kwestie dotyczace przestrzennego i chronologicznego funkcjonowania systemu dochodów w szesnastowiecznej Koronie na przykładzie Wielkopolski. Zakres chronologiczny analizy obejmuje okres od przełomu XV i XVI w., kiedy zaczą się tworzyć polski system parlamentarny, do początków XVII w., a dokładnie do momentu powołania Trybunału Skarbowego Koronnego w 1613 r. Autorzy próbuja odpowiedzieć na pytanie o adekwatność perspektywy przestrzenno-chronologicznej dla badań nad historia opodatkowania poprzez analizę wybranych aspektów procesu poboru podatków nadzwyczajnych. W pracy omówiono również kwestię zmian systemu dochodów Korony - od modelu centralnego, w którym decyzje dotyczące podatków podejmowane były przez Sejm, a proces poboru kontrolowany był przez monarchę za pośrednictwem urzędników dworskich, do decentralizacji, gdy coraz większą rolę w zarządzaniu finansami państwowymi zaczęły odgrywać lokalne sejmiki szlacheckie.

The content outline: The article deals with issues related to the spatial and temporal functioning of the revenue system in the sixteenth-century Crown of the Kingdom of Poland, on the example of Greater Poland. The chronological scope of the work covers the period from the turn of the fifteenth century, when the Polish parliamentary system had begun to take shape, to the early seventeenth century, or more precisely, to the establishment of the Crown Treasury Tribunal in 1613. The authors make an attempt to determine the suitability of the spatio-temporal perspective in the research on the history of taxation by analysing selected aspects of the extraordinary tax collection process. The study presented here also touches upon the problems related to the transformation occurring in the revenue system of the Crown. The system 
gradually changed from the centralised model, with decisions regarding tax matters being made by the Sejm while the monarch exacted control over the process through his officials, to a more decentralised model, in which local nobility assemblies played a greater role in managing state finances.

Słowa kluczowe: geografia historyczna, finanse państwowe, gospodarka historyczna, nowożytność, historia Polski, Korona Polska, podatki, historyczny GIS

Keywords: historical geography, state finances, historical economy, early modern period, history of Poland, Polish Crown, taxes, historical GIS

\section{Introduction}

\subsection{Historical context}

Kamieniec Castle, located in a town near Poland's south-eastern border, was a key strategic point in the defence of this part of the country. John I Albert, the king of Poland towards the end of the fifteenth century, knew that the maintenance of the stronghold required a sizeable army force; he was also well aware that the country's financial situation was abysmal. His mood could not have been improved by a letter he received in the summer of 1499 from the commander of the mercenary force stationed at the castle; dated the $27^{\text {th }}$ of July, the letter addressed the issue of payment for the soldiers, which would allow further defence of the border from the Tatar cavalry, at the time a profound threat to the local populace. The commander wrote about the grave situation at the outpost: "If only His Royal Highness would compensate us for our duty, we would serve His Royal Highness with all due loyalty to our sovereign, and a sovereign most beloved." "The king was faced with a choice of either paying the soldiers or leaving the stronghold unmanned, which would result in its loss. And John Albert would have remembered the circumstances of the Malbork conquest of 1457. The Teutonic Order's control of one of the mightiest strongholds of contemporary Europe was lost by means of the Polish commander's reimbursement of the unpaid Bohemian mercenaries stationed there, who in turn gave up control of the castle to the Polish troops.

The example above does not pertain to any specific time or place, but is rather symptomatic of a wider problem persisting in every single

${ }^{1}$ Listy i akta Piotra Myszkowskiego, generalnego starosty ziem ruskich króla Jana Olbrachta zebrane przez śp. Adolfa Pawińskiego, ed. A. Lewicki, Kraków, 1898, no. 32. The quote comes from a captains' letter to the king, and was originally written in Ruthenian with the use of the Latin alphabet. 
country throughout history: how to get funds to run a country and make politics? A reliable solution (though one that has never proved to be completely satisfactory) has always been, and still is, to raise funds through taxation. The way taxes are implemented, collected, accounted, and managed, shapes the revenue system of any given country and allows it to function as a country in the first place.

The present article analyses the revenue system, specifically the organisation of tax collection, in Poland from the end of the fifteenth century to the beginning of the seventeenth century. During this period, European countries saw the emergence of two trends that shaped their revenue models: the first entailed numerous reforms aimed at transforming revenue systems based on feudal domain models to ones befitting the conditions of strictly controlled and centralised fiscal states; the second was the military revolution that occurred with the introduction and development of gunpowder weapons, significantly driving up the costs of war and prompting monarchs of the late Middle Ages and the early modern period to accept reforms that would provide increasing amounts of money to the state. ${ }^{2}$ Poland was also affected by these processes, which were further exacerbated by the country's particular political system.

The Crown of the Kingdom of Poland (the Crown) and the Grand Lithuanian Duchy were joined in a personal union in the fifteenth century, eventually coalescing into a real union in 1569 and forming the Polish-Lithuanian Commonwealth. Although the king (from 1573 onwards chosen by the nobility by means of a royal election) formally ruled the country, the final say in state matters belonged to the nobility, empowered by numerous charters granted by various monarchs throughout centuries. Among other perks, some privileges entailed tax relief for the nobility, which was one of the reasons for the chronic fiscal deficit in the country. The charters were also a key factor in the shaping of the Polish political system (monarchia mixta),${ }^{3}$ which resulted in

${ }^{2}$ For more about the transition from the feudal quit-rent revenue system to the fiscal system involving regular and extraordinary taxes see G. Myśliwski, "From Feudal Rents towards a Tax System in Central Europe (the Thirteenth to the Fifteenth Century)," in: La fiscalità nell'economia Europea secc. XIII-XVIII. Fiscal Systems in the European Economy from the $13^{\text {th }}$ to the $18^{\text {th }}$ Centuries, ed. S. Cavaciocchi, Firenze, 2016, pp. 271-278. For more information on the influence of wars on the development of revenue systems, see e.g.: the anthology War and Economic Development. Essays in Memory of David Joslin, ed. J.M. Winter, Cambridge, 1975; Ph. Contamine, War in the Middle Ages, Oxford, 1984.

${ }^{3}$ More detailed information on the topic of the formation of the Polish state in the modern times can be found in the university handbook U. Augustyniak, Historia 
the formation of the parliament - the Polish (later Polish-Lithuanian) Sejm, the primary governing institution of the Commonwealth. In the sixteenth century, the Sejm consisted of three bodies - the king, the Senate (consisting of landowners and high-ranking clergy), and the lower house of representatives (consisting of nobles elected at sejmiki, which were local diets). The Sejm was supposed to assemble every two years, though it was common for assemblies to occur more frequently. ${ }^{4}$ While that period is rightfully considered to have been the most prominent in the historical development of parliamentary culture in Poland, the rampant growth in charter-issued prerogatives, the need to negotiate every single statute with the nobility, as well as the foreign policies of the kings, which sometimes inevitably led to armed conflict, all contributed to the chronic fiscal deficit in the Crown's Treasury. ${ }^{5}$

One of the ways to mend the ailing finances of the country was to issue extraordinary taxes, which at the time were in fact the main source of revenue. ${ }^{6}$ The taxes had to be approved by the Sejm each time. They were imposed to meet specific needs of the country, usually concerning the military and wartime defence. For example, during the Sejm in 1563-1564, the revenue from these taxes was used to defend the borders, and the income from the 1578 extraordinary tax was spent on the war with Moscow; ${ }^{7}$ in reality, the money was used differently depending on the current state needs. These extraordinary taxes, though still insufficient, proved to be highly effective in improving the financial

Polski. 1572-1795, Warszawa, 2008. For classical literature on the subject see A. Wyczański, Polska rzecza pospolita szlachecka: 1454-1764, Warszawa, 1965, or the anthology of studies: Polska $w$ dobie odrodzenia. Państwo - społeczeństwo - kultura, ed. A. Wyczański, Warszawa, 1970.

${ }^{4}$ W. Konopczyński, Chronologia sejmów polskich 1493-1793, Kraków, 1948.

${ }^{5}$ For example, A. Sucheni-Grabowska, Odbudowa domeny królewskiej $w$ Polsce 1504-1548, Warszawa, 2007 ( $1^{\text {st }}$ edition 1967) and K. Chłapowski, Realizacja reform egzekucji dóbr (1563-1665): sprawa zastawów królewszczyzn małopolskich, Warszawa, 1984.

${ }^{6}$ For more on the structure of the revenue see: K. Boroda, P. Guzowski, "From King's Finance to Public Finance. Different Strategies of Fighting Financial Crisis in the Kingdom of Poland under Jagiellonian Rule (1386-1572)," in: La fiscalità nell'economia Europea..., pp. 451-470.

7 Volumina Constitutionum, vol. 2, part 2, ed. S. Grodziski, Warszawa, 2008, pp. 146-147, 422. Studies on the period directly preceding this one: T. Brzeczkowski, "Ustanawianie podatków nadzwyczajnych w Polsce w XV w.," RDSG 42, 1981, pp. 77-105; T. Szulc, "O dysponowaniu wpływami z podatków nadzwyczajnych w Polsce XV wieku," KH 99, 1992, fasc. 2, pp. 39-50; T. Szulc, "Przeznaczenie a wydatkowanie kwot z podatków nadzwyczajnych z dóbr szlacheckich w Polsce XV wieku," KH 100, 1993, fasc. 2, pp. 15-26. 
situation of the country, and the sixteenth century saw a rise in the frequency of their implementation, which was paired with an increase in ordinary taxation on a multitude of social groups and economic areas.

In this article we analyse the phenomenon of extraordinary tax collection on a local level and in its wider spatio-temporal context, taking into consideration the timeline and the geographical scope of the sources. This kind of approach was not widely applied in past literature, therefore we hope that by assessing the merits of such a perspective on revenue system analysis, we could pave the way for further research in the field. Spatial analysis of sources will allow us to take a closer look at factors that played a role in the implementation of extraordinary taxes, as well as to grasp the nuanced changes that occurred in this system during the sixteenth century. Particular stages of the implementation of extraordinary taxes will be analysed as well, starting from the motion to begin the taxation process to the general temporal scope of such an endeavour. We will also specify the personnel responsible for the choice of purposes on which the tax revenue would be spent and give examples of the collection of outstanding taxes.

Because the history of tax collection, especially in the Polish-Lithuanian Commonwealth, is closely connected to a wider spectrum of research topics, such as the history of state administration, the political system, the society, and economy of the country, we would like to present how the spatio-temporal aspect of tax collection could help researchers in the reconstruction of administrative borders and help ascertain the placement of towns and villages on administrative maps. Additionally, this study can become an aid in the identification of traps awaiting researchers who analyse period fiscal sources without considering their wider context.

The geographical area of our analysis is the western part of the Polish state - Greater Poland, which encompassed two voivodeships: Poznań and Kalisz (Fig. 1). Poznań Voivodeship, with its seat in Poznań, was divided into four districts (Pol. powiaty, sing. powiat; Lat. districtus): Wałcz, Poznan, Kościan, and Wschowa, the last of which also held the status, and the autonomy, of a land (Pol. ziemia). Kalisz Voivodeship, with the seat in Kalisz, consisted of six districts: Nakło, Kcynia, Gniezno, Konin, Pyzdry, and Kalisz. The particularity of Greater Poland was the fact that most of its area (seven districts) was under the supervision of one general starost (Pol. starosta generalny Wielkopolski, Lat. capitaneus generalis Maioris Poloniae - governor of crown demesne in Greater Poland and chief of the local administration) and not scattered among minor starostwa grodowe (Wschowa, Wałcz, and Nakło Districts had 


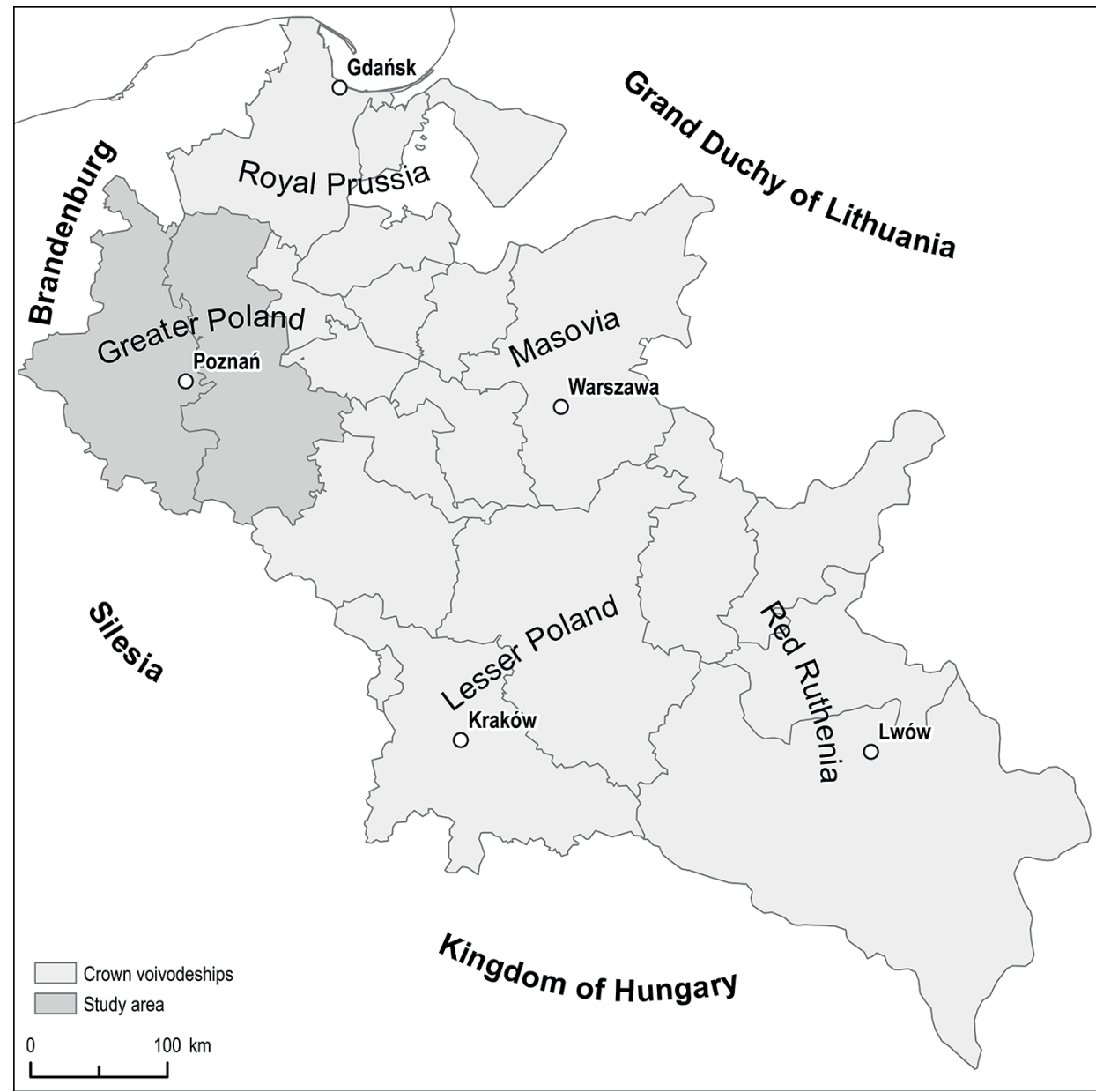

Fig. 1. Crown of the Kingdom of Poland before the Lublin Union (1569); elaborated by T. Panecki

their own autonomous starosts). We have also chosen the area because it has recently been the subject of research on both administration and settlement; ${ }^{8}$ additionally, there are viable sources, such as tax registers

${ }^{8}$ Some of the more important sources on the subject: Wielkopolska $w$ drugiej połowie XVI w., eds. K. Chłapowski and M. Słoń, Warszawa, 2017 (Atlas historyczny Polski. Mapy szczegótowe XVI w., vol. 4).; A. Gąsiorowski, Powiat w Wielkopolsce XIV-XVI wieku: z zagadnień zarzqdu terytorialnego i podziatów Polski późnośredniowiecznej, Poznań, 1965; id., Urzędnicy zarzqdu lokalnego w późnośredniowiecznej Wielkopolsce, Poznań, 1970; Urzędnicy wielkopolscy 1385-1500. Spisy, ed. A. Gąsiorowski, Poznań, 1968; A. Bieniaszewski, "Urzędnicy wielkopolscy XVI-XVIII wieku. Spisy," in: Urzędnicy dawnej Rzeczypospolitej XII-XVIII wieku. Spisy, vol. 1, part 2, 
and local diet (sejmiki) records ${ }^{9}$ available for analysis. The research we have done recently during the elaboration of the last volume of the Historical Atlas of Poland has proved to be a valuable addition to the existing literature on Greater Poland in the sixteenth century. ${ }^{10}$

\subsection{Source materials}

In the late Middle Ages and the early modern period, the revenue that constituted the general income of the Crown could be divided into regular sources of income, continuously used since the fourteenth century, and those that only occasionally were used to line the king's coffers. ${ }^{11}$ Regular income was generated by poradlne (plough tax - paid by nobles' peasants, 2 groshes per mansus - a historical unit of farmland measurement ${ }^{12}$ ), revenue from royal demesne scattered around the country (Pol. królewszczyzna), salt mine revenue from mines located in Lesser Poland and Ruthenia, and the working system of tariffs and tolls.

As the main focus of our article are the spatial mechanisms of extraordinary tax collection, it would be appropriate to introduce the topic here. The extraordinary tax was continuously implemented in the Crown from the second half of the fifteenth century, with its popularity peaking in the sixteenth century, during the reign of Sigismund I the Old and

ed. A. Gasiorowski, Wrocław, 1987; J. Bielecka, "Organizacja i działalność kancelarii ziemskich i grodzkich wielkopolskich XIV-XVIII w.," Archeion 22, 1954, pp. 129-155; id., "Kancelaria grodzka wielkopolska w XVI-XVIII wieku," St. Źródt. 1, 1957, pp. 120-155; id., Inwentarze ksiag archiwów grodzkich i ziemskich Wielkopolski XIV-XVIII wieku: Województwo poznańskie, kaliskie, gnieźnieńskie, inowrocławskie, Poznań, 1965.

${ }^{9}$ Akta sejmikowe województw poznańskiego i kaliskiego, vol. 1: 1572-1632, part 1, 1572-1616, ed. W. Dworzaczek, Poznań 1957 (further: ASWPK); "Rejestry poborowe województwa kaliskiego w XVI wieku," ed. M. Słoń, Atlas Źródet i Materiałów z Dziejów Dawnej Polski, vol. 2, 2015, http://atlasfontium.pl (10 X 2018) (further: RPWK); "Rejestry poborowe województwa poznańskiego w XVI wieku,” ed. M. Słoń, Atlas Źródet i Materiałów z Dziejów Dawnej Polski, vol. 3, 2015, http://atlasfontium.pl (10 X 2018) (further: RPWP). See also: S. Płaza, Sejmiki i zjazdy szlacheckie województw poznańskiego $i$ kaliskiego. Ustrój i funkcjonowanie (1572-1632), Warszawa-Kraków, 1994.

${ }^{10}$ M. Słoń, “'́ródła pisane," in: Wielkopolska w drugiej połowie XVI wieku, pp. 20 -28; M. Gochna, "Podziały administracyjne. Granice państwowych jednostek terytorialnych," in: Wielkopolska $w$ drugiej połowie XVI wieku, pp. 46-64.

${ }^{11}$ A research topic which we have decided not to discuss in this study is the separation of public and royal funds, which was initiated in the Crown in 1510. More on the topic: A. Sucheni-Grabowska, op. cit., pp. 231-233.

12 A single mansus (Pol. tan, pl. tany) could have a different size depending on the region, varying from around 16 hectares (40 acres) to as much as 24 hectares (60 acres) of land (trans.). 


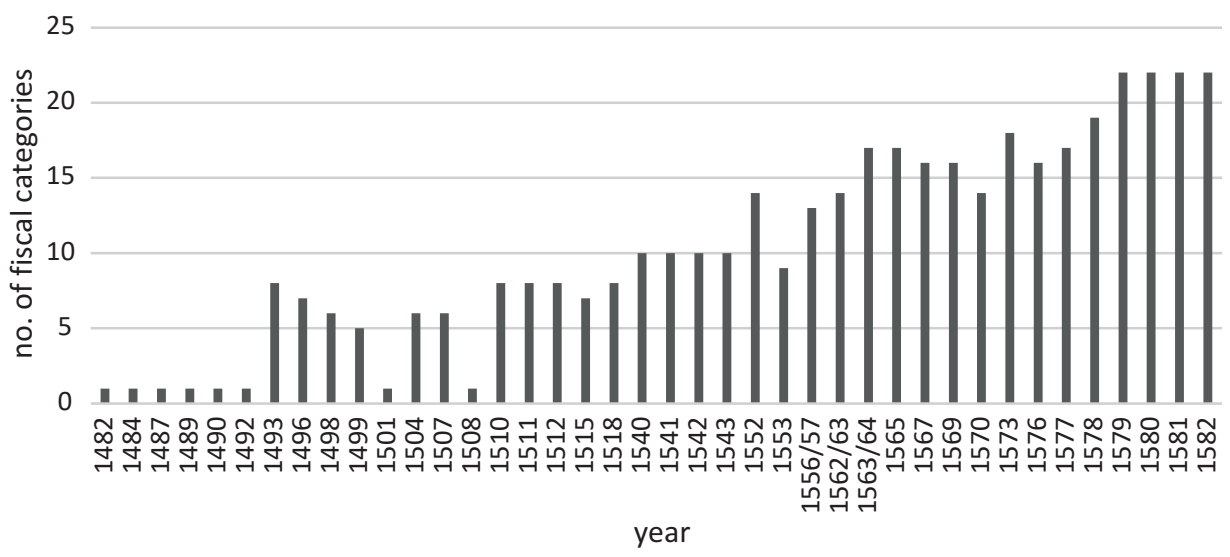

Fig. 2. Some examples of the composition of fiscal categories towards the end of the fifteenth century and in the sixteenth century. Source data before 1482 and between 1518-1538/39 has been omitted in this elaboration; after: K. Boroda, "Kmieć, łan czy profit? Co było podstawa poboru łanowego w XV i XVI wieku?" in: Człowiek wobec miar i czasu w przeszłości, eds. P. Guzowski and M. Liedke, Kraków, 2007, pp. 168-170.

his son, Sigismund II Augustus. ${ }^{13}$ It had the form of a lump-sum payment that was initially based on the number of mansi (cultivated by peasants and belonging to the nobility, the clergy, the king, or a town, Lat. mansi possessionati). Each decade of the sixteenth century brought new tax categories meant to increase state revenue. ${ }^{14}$ There were three fundamental stages to the increase: the turn of the fifteenth century (ca. 1496-1511/1515), when the Crown was attempting to end the crisis caused by the pledge of crown land, the 1560s and the Sejmy egzekucyjne (during which the nobility movement called ruch egzekucyjny successfully pressed for economic and state reform), and the period between the 1570s and 1580s, when the country was involved in various armed conflicts and the struggle for succession that followed the childless death of Sigismund Augustus. Each of these periods brought forth a new wave of extraordinary land tax: at the beginning of the sixteenth century, a tax on property generating income (i.e., watermills, windmills, fulling mills, and sawmills) was introduced, followed by a tax placed on particular social groups: those holding the function of the soltys (Lat. scultetus, local feudal lord's representative), petty gentry

${ }_{13}$ Extraordinary taxes were also introduced by kings Sigismund III Vasa and Stephen Báthory, though their popularity waned in the seventeenth century.

${ }^{14} \mathrm{~K}$. Boroda, "Kmieć, łan czy profit? Co było podstawą poboru łanowego w XV i XVI wieku?," in: Człowiek wobec miar i czasu w przeszłości, eds. P. Guzowski, M. Liedke, Kraków, 2007, pp. 168-170. See also P. Guzowski, K. Boroda, op. cit., pp. 463-465. 
(Pol. szlachta zagrodowa), gardners (Pol. zagrodnicy), and people who settled according to the Vlach law; the end of the sixteenth century extended taxes to servants, landless labourers, glassmiths, brewers, tar and pitch makers, smiths, peasants assigned to fallow fields (mansi deserti), and finally, inhabitants of dedicated villages ${ }^{15}$ (Pol. wsie stu$\dot{z}$ ebne, specialising in the production of certain goods, such as honey or fish; Fig. 2). The revenue generated from those taxes was an important source of income in early modern Poland; for example, around 1560, the Crown's income amounted to 445,000 florins, out of which 240,000 florins $(54 \%)$ came from extraordinary taxes. ${ }^{16}$ The rest was regular revenue: income from salt mines $(48,000,11 \%)$, tariffs $(67,000,15 \%)$, and royal demesne $(90,000,20 \%)$.

The most important historical sources on extraordinary tax implementation and collection are tax registers (Pol. sing. rejestr poborowy, Lat. regestrum contributionum) ${ }^{17}$ Their form did not change significantly throughout our period of interest. Two types of registers can be distinguished: table registers (Fig. 3) and text-and-table registers (Fig. 4) ${ }^{18}$ A great majority of these registers (though exceptions from the rule did occur) were composed of alphabetic lists of parishes, as well as lists of towns and villages that belonged to the parish. Throughout the consecutive decades of the sixteenth century, tax registers began to feature more economic information, such as the exact amount of taxed land, its owner, the number and types of production-based properties, the number of artisans or servants, etc.; there were also more details relevant to tax collection, such as the date of payment or information on who had brought in the tax.

The greatest collection of Polish tax registers and other materials related to historical fiscal system is currently stored in the Archives of the Crown Treasury (Pol. Archiwum Skarbu Koronnego) located in the Central Archives of Historical Records in Warsaw (Pol. Archiwum Główne Akt Dawnych w Warszawie); however, a great part of the data we used in this study, mainly judicial, is scattered in archival court files around the country, which often made the source material hard

${ }^{15}$ K. Boroda, op. cit., pp. 168-170.

16 P. Guzowski, K. Boroda, op. cit., p. 466.

${ }^{17}$ M. Słoń, "Digitale Edition der Ausheberregister aus der Wojewodschaft Kalisch des 16. Jahrhundert," in: Editionswissenschaftliches Kolloquium 2011. Quellen kirchlicher Provenienz neue Editionsvorhaben und aktuelle EDV-Projekte, eds. H. Flachenecker, J. Tandecki, and K. Kopiński, Toruń, 2011, pp. 393-405.

${ }_{18}$ M. Gochna, "Elektroniczna edycja rejestrów poborowych województwa kaliskiego z drugiej połowy XVI w.," Studia Geohistorica 2, 2014, p. 144. 


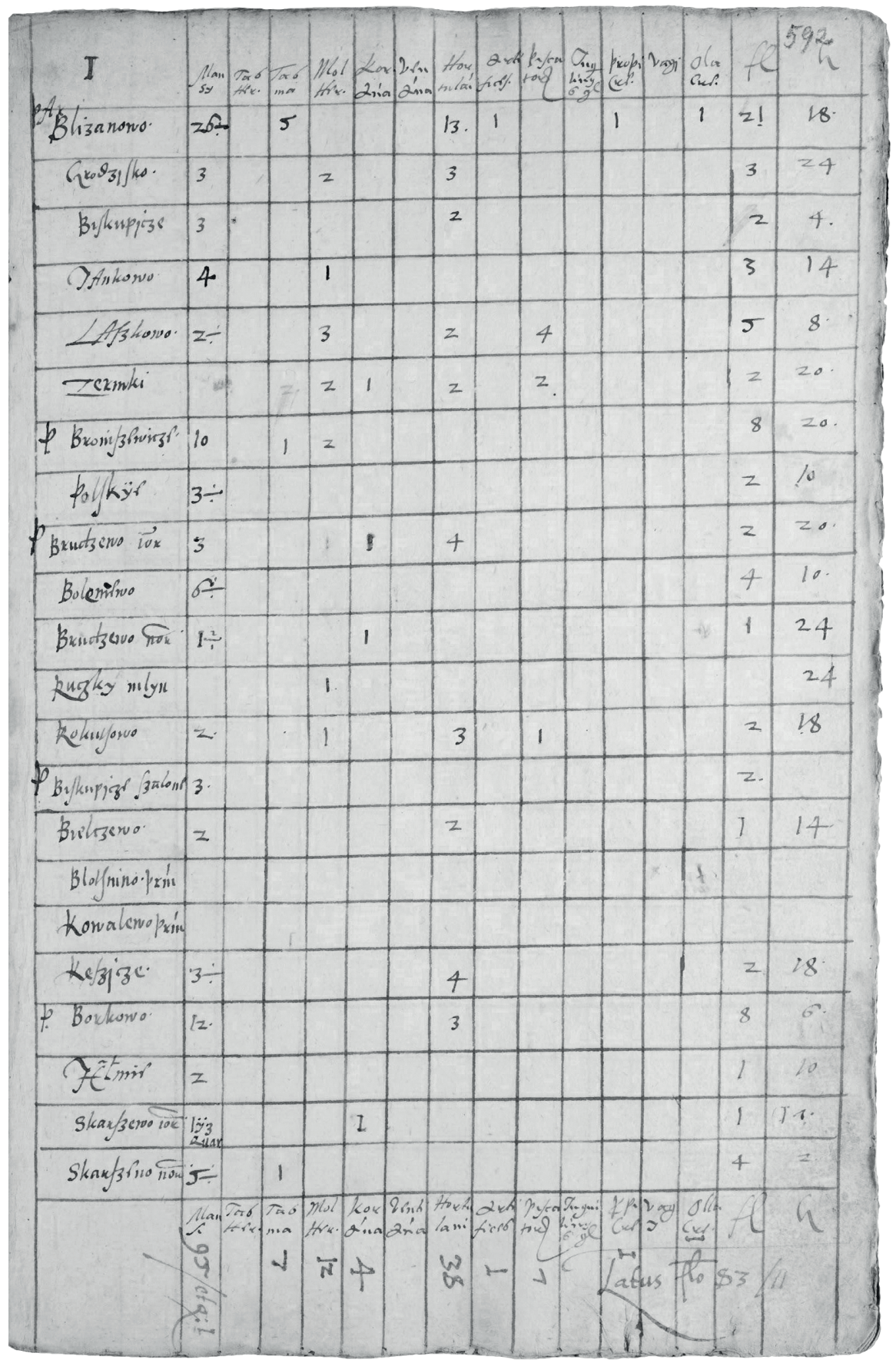

Fig. 3. A page of the extraordinary tax register of Kalisz District from 1576; AGAD, ASK I 12, f. 592 


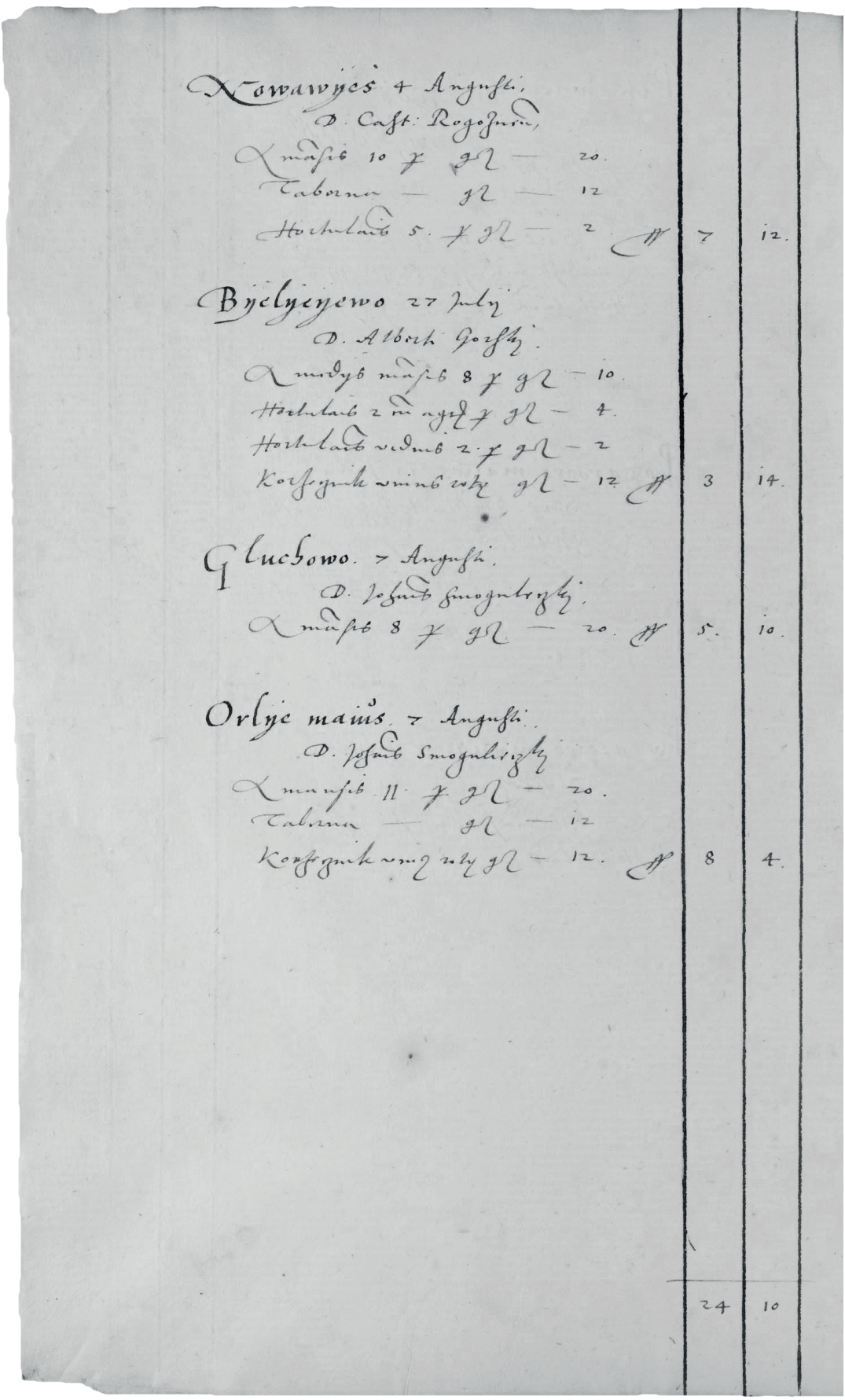

Fig. 4. A page of the extraordinary tax register of Poznan District from 1576; AGAD, ASK I 5, f. 452v 
to process due to the poor state of the documents, as well as missing, lost, or misplaced files. The lack of a complete and working system of archiving such files, either at the time when they were compiled or in later periods, is to blame for these problems. Documentation regarding the revenue system was described in historical inventory lists of the Archives of the Crown Treasury as "old papers" and was stored in sacks haphazardly strewn over the archive rooms. ${ }^{19}$ Some materials, such as recognitiones (Pol. rekognicjarz, a list of statements made by taxpayers at the moment of paying the $\operatorname{tax}^{20}$ ), were made unavailable to the Treasury officials as some functionaries tended to consider state documents to be their own private property. Many of those sources were also destroyed during World War II. ${ }^{21}$

\section{Spatial and temporal aspects of extraordinary tax collection}

\subsection{Introducing taxes}

The legal basis for tax introduction was a special legal tax act called uniwersat (Pol. uniwersaty, Lat. littera universalis), a document compiled (together with other resolutions) after a session of the Sejm had been concluded. The legal act was then sent to all local municipalities in the district in order to quickly and widely spread awareness of the implementation of the tax. Uniwersaty dating to the second half of the period of interest in this article were often included into starost court records, such as the 1588 uniwersat entered into the starost court books of Kalisz District. ${ }^{22}$ The information itself could be spread in a number of ways: ${ }^{23}$ the text of the uniwersat could be proclaimed

19 A. Kłodziński, O Archiwum Skarbca Koronnego na Zamku Krakowskim, Kraków, 1923 (Archiwum Komisji Historycznej PAU, series 2/1), pp. 267-275.

${ }^{20}$ Current research concerning this source material was summarised in: M. Gochna, "Polish Nobility Seals in the 'recognitiones' of the Kalisz district in 1591. The perspective of an Edition," in: Editionswissenschaftliches Kolloquium 2015. Die Geschichte im Bild, eds. H. Flachenecker, K. Kopiński and J. Tandecki, Torun, 2016, pp. 103-108.

${ }^{21}$ J. Karwasińska, "Archiwa skarbowe dawnej Rzeczypospolitej," in: Straty archiwów i bibliotek warszawskich w zakresie rękopiśmiennych źródeł historycznych, vol. 1: Archiwum Główne Akt Dawnych, ed. A. Stebelski, Warsaw, 1956, pp. 70-125.

22 AP Poznań, Starost court books in Kalisz [Księgi sądu i urzędu grodzkiego w Kaliszu], Kalisz Gr. 243, p. 46 (Uniwersat poborowy roku M. D. LXXXVIII).

${ }^{23}$ See also: A. Pawiński, Skarbowość w Polsce $i$ jej dzieje za Stefana Batorego, Warszawa 1881, pp. 280-281. 
publicly by bailiffs in town squares; for example, in 1564 the bailiff of the land court of Kalisz District announced the text of the uniwersat in the town squares of two towns in the district, Pleszew and Kalisz. ${ }^{24}$ In the same year, the bailiffs also widely announced the upcoming introduction of liquor tax (Pol. czopowe, Lat. ducillia, a tax on the production, import, and trade of beer, wine, mead, and spirits). By looking at the cities they visited, probably listed in chronological order, the route taken by the bailiffs could be reconstructed (Fig. 5). Zygmunt of Czachory announced the royal mandate in Stawiszyn, Koźminek, Iwanowice, and Opatówek, while Piotr of Czachory announced it in Raszków, Zduny, Sulimierzyce, Odolanów, and Ostrów. ${ }^{25}$

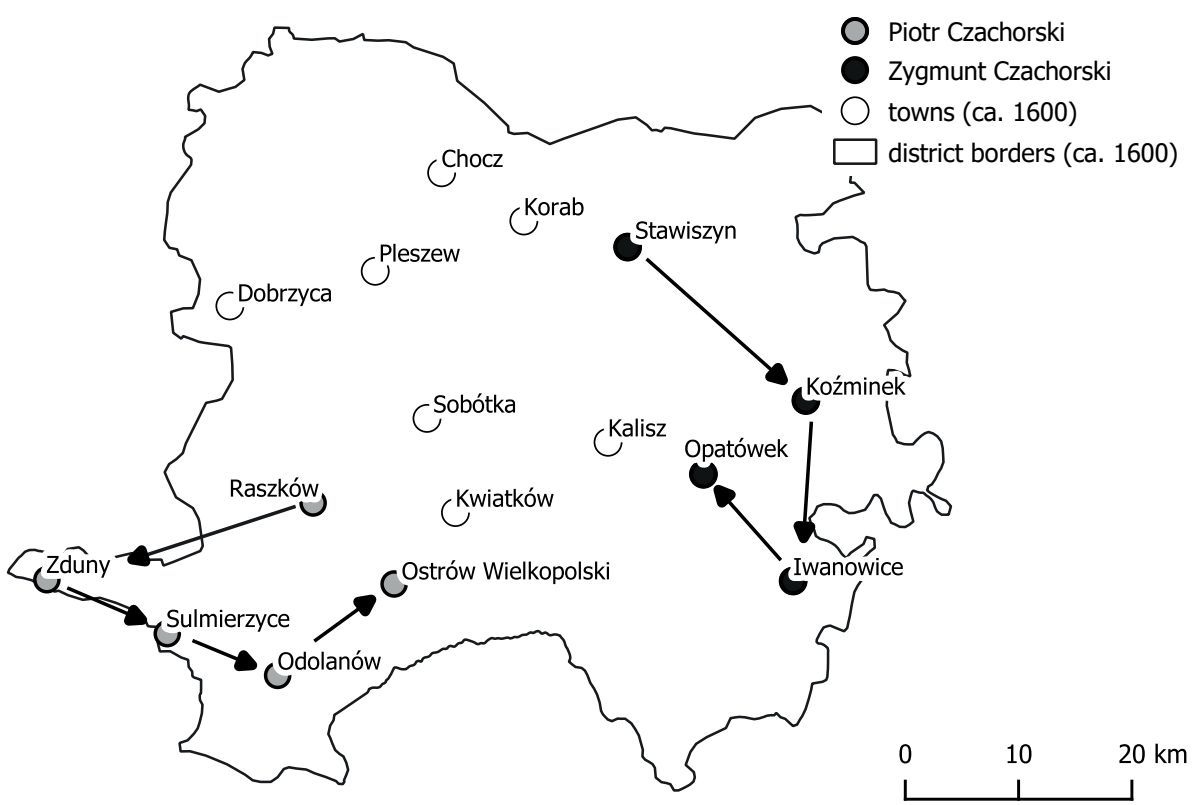

Fig. 5. The announcement of the royal decree concerning the introduction of a liquor tax in some towns of Kalisz District in 1564, by bailiffs of the land court of Kalisz District - Zygmunt Czachorski and Piotr Czachorski. Arrows indicate the order in which these towns were listed in the source

Another way to spread awareness of the tax was to read out the contents of the uniwersat in parochial churches. ${ }^{26}$ As districts were the

${ }^{24}$ AP Poznań, Kalisz Gr. 52, p. 620 (Publicatio literarum S. R. Mtis Contributionis Publicae).

${ }^{25}$ Ibid., pp. 299, 302 (Relatio moniotnis o czopowe).

${ }^{26}$ K. Chłapowski, "Rejestry poborowe. Wstęp źródłoznawczy," in: Atlas Źródeł i Materiałów do Dziejów Dawnej Polski, 2015, vol. 2: Atlas historyczny Polski. Rejestry 
smallest administrative units in the Crown at the time, parishes were often co-opted as another administrative tier. ${ }^{27}$

News of an upcoming tax were without a doubt spread in local nobility assemblies, like court assemblies or local diets, ${ }^{28}$ though this subject requires further research.

\subsection{The functional chronology of tax introduction}

The oldest surviving tax registers concerning extraordinary taxes from Greater Poland date from as late as 1507; the surviving records are for the districts of Pyzdry, Kalisz, Konin, and Poznan. The legal act introducing the extraordinary tax of 1507 was the uniwersat issued by the Sejm and the king at the beginning of March..$^{29}$ In that year, taxes were supposed to be collected sub poenis pignorationis from the $23^{\text {rd }}$ of May (Whitsun) until the $29^{\text {th }}$ of June (Feast of Saints Peter and Paul).$^{30}$ In 1508, the tax was broken down into two instalments: the first paid until the $2^{\text {nd }}$ of April (Laetare Sunday), and the second due on the $24^{\text {th }}$ of June (Nativity of Saint John the Baptist/Midsummer). ${ }^{31}$ The 1509 uniwersat introducing the tax did not survive, though it is known that the Sejm was in session towards the end of 1508 and the local diets met in January and February of $1509 .{ }^{32}$ The 1510 tax was also introduced in instalments: the first one paid between the $23^{\text {rd }}$ of April (Saint George's Day) and the $19^{\text {th }}$ of May (Whitsun), the second until the $29^{\text {th }}$ of September (Michaelmas). ${ }^{33}$

However, in the case of the 1507 extraordinary tax in Kalisz District, the collection dates in tax registers differ significantly from the ones from the uniwersat recorded in the Crown Metric (Pol. Metryka Koronna). This discrepancy could be explained by the fact that the uniwersat recorded in the Metric originated in Lesser Poland. This was

poborowe województwa kaliskiego w XVI w., ed. M. Słoń, http://atlasfontium.pl (10 X 2018).

27 Ibid.

28 J. Choińska-Mika, Między społeczeństwem a władza. Problemy komunikacji spoteczności lokalne - wtadza w epoce Jana Kazimierza, Warszawa, 2002, pp. 233-243.

${ }^{29}$ Volumina Constitutionum, vol. 1, part 1, eds. S. Grodziski, I. Dwornicka, W. Uruszczak, Warszawa, 1996, p. 199. For more information on this Sejm assembly see W. Uruszczak, "Sejm koronacyjny w 1507 r. w Krakowie," Studia z Dziejów Państwa i Prawa Polskiego 7, 2002, pp. 111-121.

${ }^{30}$ Volumina Constitutionum, vol. 1, part 1, p. 199.

${ }^{31}$ Ibid., pp. 209-210.

${ }^{32}$ Ibid., p. 211.

${ }^{33}$ Ibid., p. 236. 
pointed out almost a century ago by Oswald Balzer, who claimed that the uniwersat of 1507 had survived in two "slightly differing manuscripts" in the Crown Metric, as well as in one folio in the Archives of the Crown Treasury, containing the tax registers for the Przemyśl and Sanok Lands. ${ }^{34}$ This discrepancy could mean that the dates in the Metric uniwersat did not apply to tax collection in the entire country, but just in one province - Lesser Poland. Tax collection in Greater Poland was conducted at different dates, which is best evidenced by the difference in monthly payments. The vast majority (322) of those payments were delivered to tax collectors in September of 1507 , while only a few towns and villages paid the tax in the subsequent autumn and winter months (Fig. 6). ${ }^{35}$

In the data for the 1507 tax collection, it can be observed that thirteen payments were recorded to have been made in March of the same year. This means that the uniwersat that was the legal basis for the collection had not been issued during the coronation Sejm of Sigismund Augustus, which started on the $24^{\text {th }}$ of January and ended

${ }^{34}$ Ibid., p. 199. The Lesser Polish and Ruthenian character of these manuscripts is evidenced by the titles listed there: "Littere universales super exactione fertonum per terras Cracoviensem, Sandomiriensem, Chelmensem, Belzensem, Leopoliensem, Praemisliensem et Sanocensem misse"; Volumina Constitutionum, vol. 1, part 1, p. 199 , footnote b.

35 An example of this mechanism can be found in the town register of Kalisz (AP Poznań, Kalisz Gr. 31, ff. 210v-211r), where it is noted that the Ostroróg brothers were charged with a fine of 14 grzywny for non-payment of land tax from the following villages: Osuchów, Chodybki, Nowy Nakwasin, Złotniki, and their manorial property in Dębsko (Dampsko de parte Ostrorog). The entry in the town register comes from the $11^{\text {th }}$ of December 1507 (feria sexta proxima inter octavas Concepcionis Marie Virginis $A D$ 1507), as does the entry in the tax register, where the same date was recorded for Złotniki; Archive of the Crown Treasury (Archiwum Skarbu Koronnego), archive division in The Central Archives of Historical Records in Warsaw (further: AGAD, ASK) I 12, f. 5. A day earlier payments from the Ostroróg estate were recorded for Chodupki and Nowy Nakwasin; AGAD, ASK I 12, f. 5. It is known that the tax payment for both Chodupki and Osuchowo was brought to Kalisz by a peasant called Jakub (probably the same person for both). All entries for these villages in the tax register were also noted down by the same scribe. The tax from Dębsko was paid as late as January 1508, after Epiphany. The comparison of the court book against the tax register shows that towards the end of the Middle Ages and the early modern period, it was the village's landlord who was formally responsible for the collection of extraordinary taxes, though the rural community could participate in this duty almost on equal ground with the landlord. The note also shows that, for the most part, taxes in Greater Poland were collected in September and October of 1507. Payments made after the due date were probably treated the same as tax arrears and the village owners were charged with 14 grzywny, and the peasants were obliged to settle the outstanding taxes. 


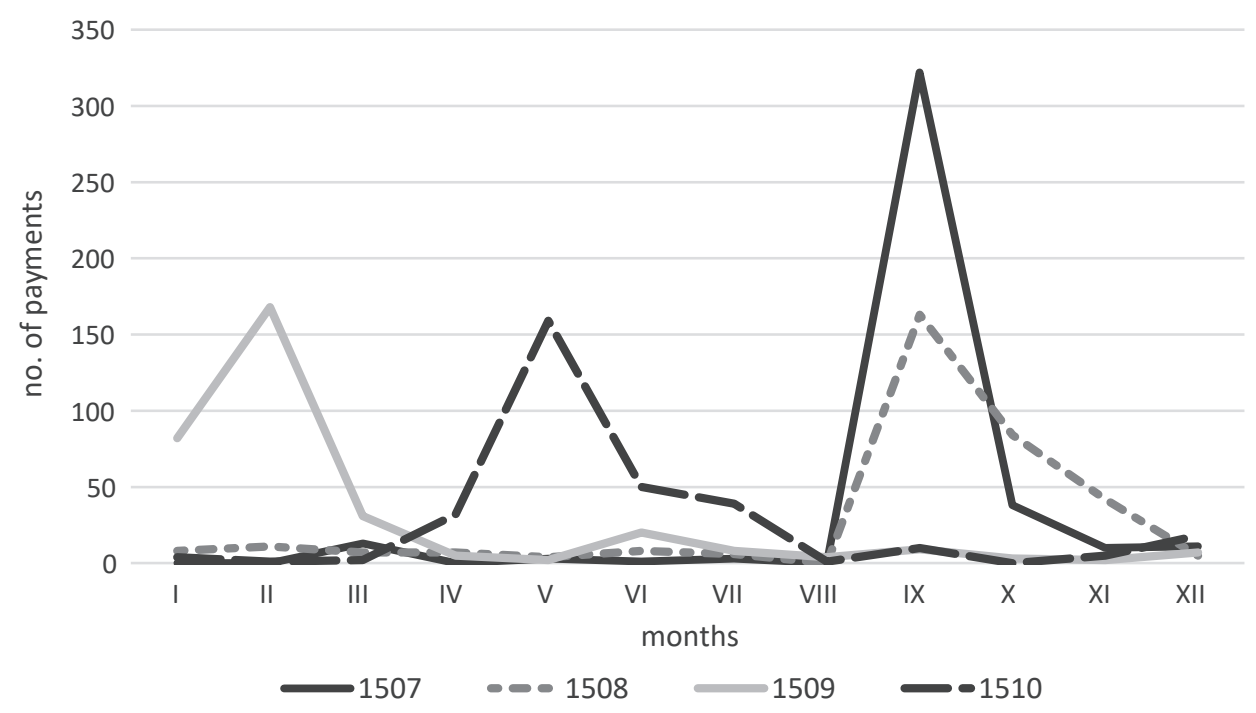

Fig. 6. The number of tax payments (by month) in Kalisz District in 1507, 1508, 1509 and 1510 (first instalment)

on the $8^{\text {th }}$ of March. ${ }^{36}$ Handwriting analysis also seems to suggest that the tax could not have been collected at the time: the vast majority, $93 \%$ of payment records from September to December were recorded by scribe A, 6\% were written down by Andrzej Wyszanowski (scribe B), and $1 \%$ by scribe $\mathrm{D}$. In the case of records made in March, only $38 \%$ were made by scribe A, 54\% by Andrzej Wyszanowski, while 7\% can be identified as entered by scribe $\mathrm{D}$. This leads to the conclusion that in Greater Poland the extraordinary tax of 1507 was collected in the autumn, while the March payments were tax arrears paid in March of 1508, perhaps completing payments that had not been paid in full before.

Evidence for the extended time for tax collection as compared to the periods provided in the uniwersaty can also be found in the records regarding manorial divisions (Pol. dziat, Lat. sors) in the village of Sobiesęki (Fig. 7) ${ }^{37}$ Payments recorded in Sobiesęki concerned two divisions, one belonging to the Stawski family (de parte Stawski) and the other to the noble John Zaręba from Kalinowa (de parte Zaramba). The payment on the first property, supplied by the local lord for 8 peasant's mansi (Lat. mansus cmethonalis/possesionatus), was made "in vigilia Circumcisionis Domini [31 XII] 1507." However, the payment for the other property of 4.5 peasant's mansi was made on the Thursday after

\footnotetext{
36 Volumina Constitutionum, vol. 1, part 1, p. 185.

37 AGAD, ASK I 12, f. 11.
} 


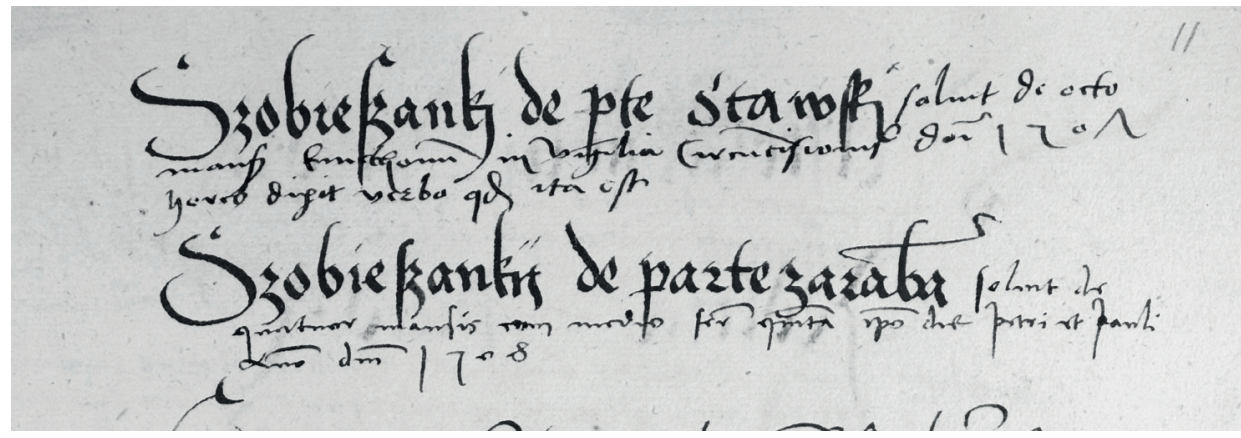

Fig. 7. A fragment of the tax register with entries concerning particular manorial divisions in the village of Sobiesęki in Kalisz District. Source: AGAD, ASK I 12, f. 11

the Feast of Saints Peter and Paul, on the 30"h of June 1508 ("feria quinta post die Petri et Pauli anno domini 1508").

While uniwersaty, as legal acts, did specify the time allotted for tax collection, the dates were not strictly observed even in the second half of the sixteenth century. According to the uniwersat dated the $14^{\text {th }}$ of April 1565, the collection of taxes was supposed to end on the $24^{\text {th }}$ of August of the same year; ${ }^{38}$ however, in Kościan District, first payments were made on the $27^{\text {th }}$ of August, while the last payment was delivered on the $2^{\text {nd }}$ of March 1567 (Fig. 8). ${ }^{39}$ Most payments (503 out of 646) were made between March and July of 1566. Moreover, there were also delays in payments in Wschowa Land, where collection lasted from the $29^{\text {th }}$ of October 1565 to the $3^{\text {rd }}$ of November 1566, a bit more than a year. ${ }^{40}$

Similar delays could be observed in 1577 . The uniwersat specified the due date for tax payments on the $29^{\text {th }}$ of September, ${ }^{41}$ while in Poznan District the vast majority of payments were made between the $24^{\text {th }}$ of August and the $26^{\text {th }}$ of December (the last one on the $7^{\text {th }}$ of August 1578; Fig. 9), ${ }^{42}$ in Wschowa Land between the $1^{\text {st }}$ of September and the

${ }^{38}$ Volumina Constitutionum, vol. 2, part 1, eds. W. Uruszczak, S. Grodziski, I. Dwornicka, Warszawa, 2005, p. 189.

${ }^{39}$ For 742 entries in the 1565 tax register for Kościan District, 644 entries were dated according to the day, two only list a month, five list the year of payment, and 91 are undated; RPWP, ksc, 1565.

${ }^{40}$ In the 1565 tax register for Wschowa Land all 55 entries were dated according to the day; RPWP, wch, 1565.

${ }^{41}$ Volumina Constitutionum, vol. 2, part 1, p. 402.

${ }^{42}$ In the 1577 tax register for Poznan District, for 842 entries, 740 were dated according to the day, and 102 were not dated; RPWP, pzn, 1577. 


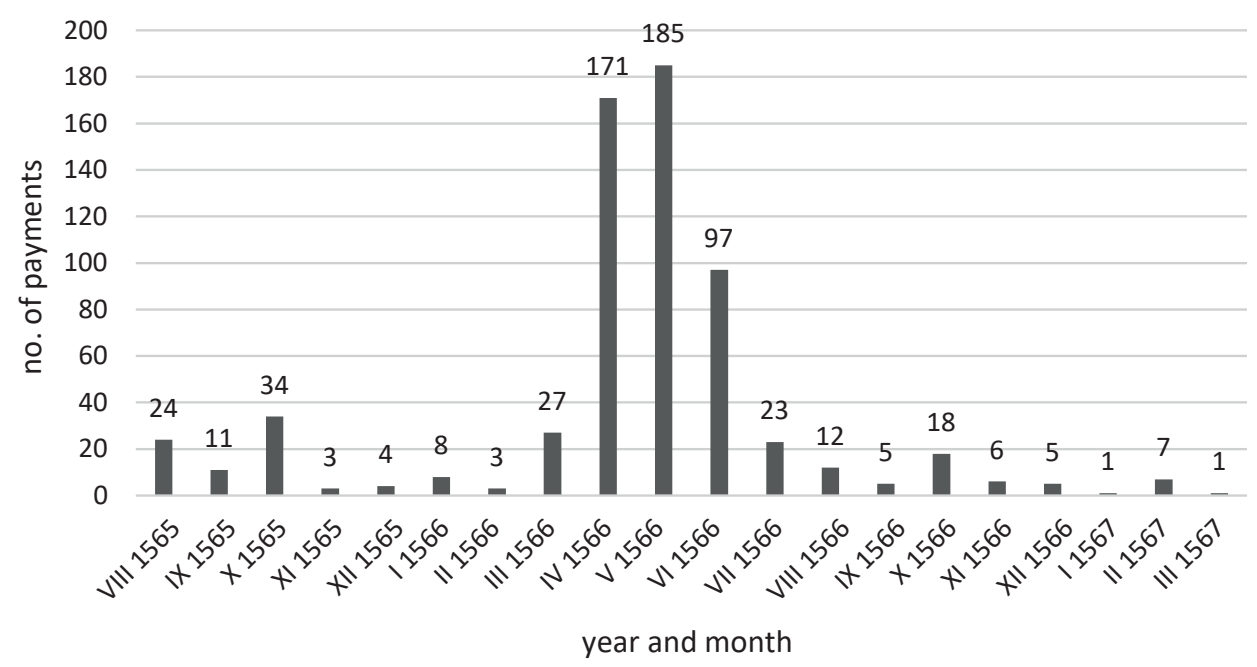

Fig. 8. The number of tax payments (by month) in Kościan District in 1565

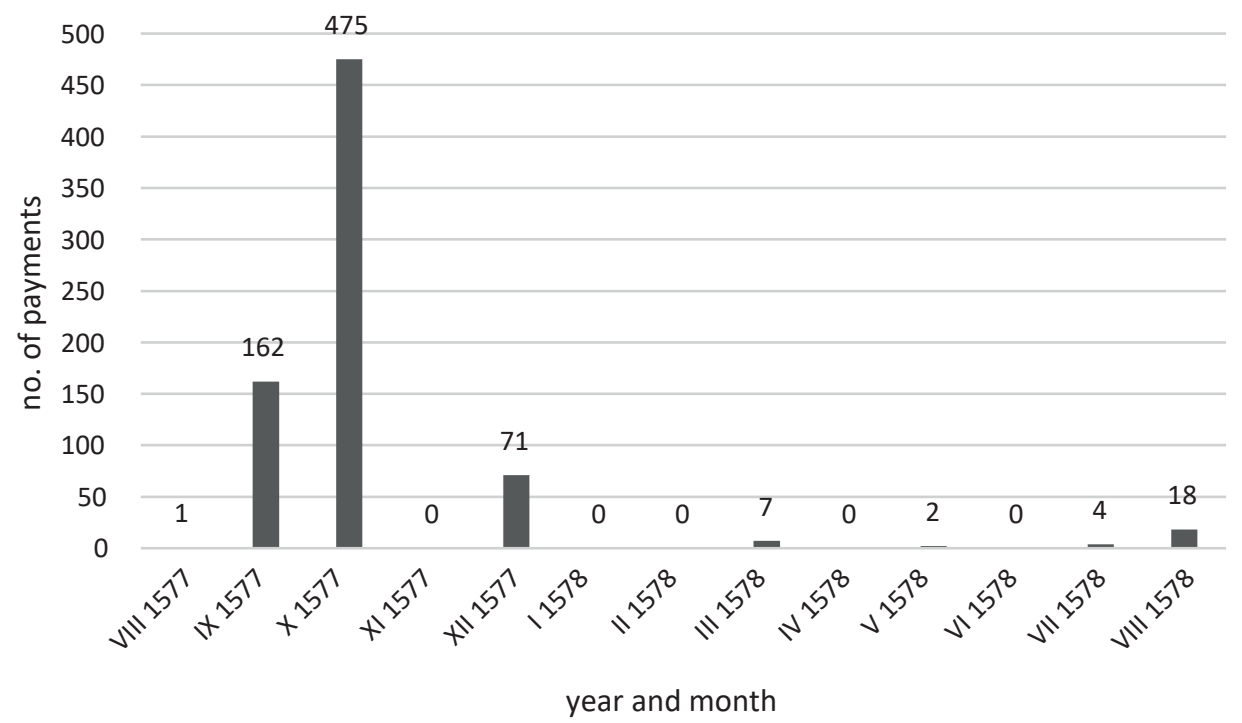

Fig. 9. The number of tax payments (by month) in Poznań District in 1577

$26^{\text {th }}$ of October (the last one on the $1^{\text {st }}$ of February 1578; Fig. 10), ${ }^{43}$ and in Pyzdry District between the $29^{\text {th }}$ of July and the $30^{\text {th }}$ of October (the last one on the $10^{\text {th }}$ of December; Fig. 11)..$^{44}$

${ }^{43}$ In the 1577 tax register for Wschowa Land, for 56 entries, 54 were dated according to the day, while two were not dated; RPWP, wch, 1577.

${ }^{44}$ In the 1577 tax register for Pyzdry District, for 507 entries 315 were dated according to the day, 192 are not dated; RPWK, pzd, 1577. 


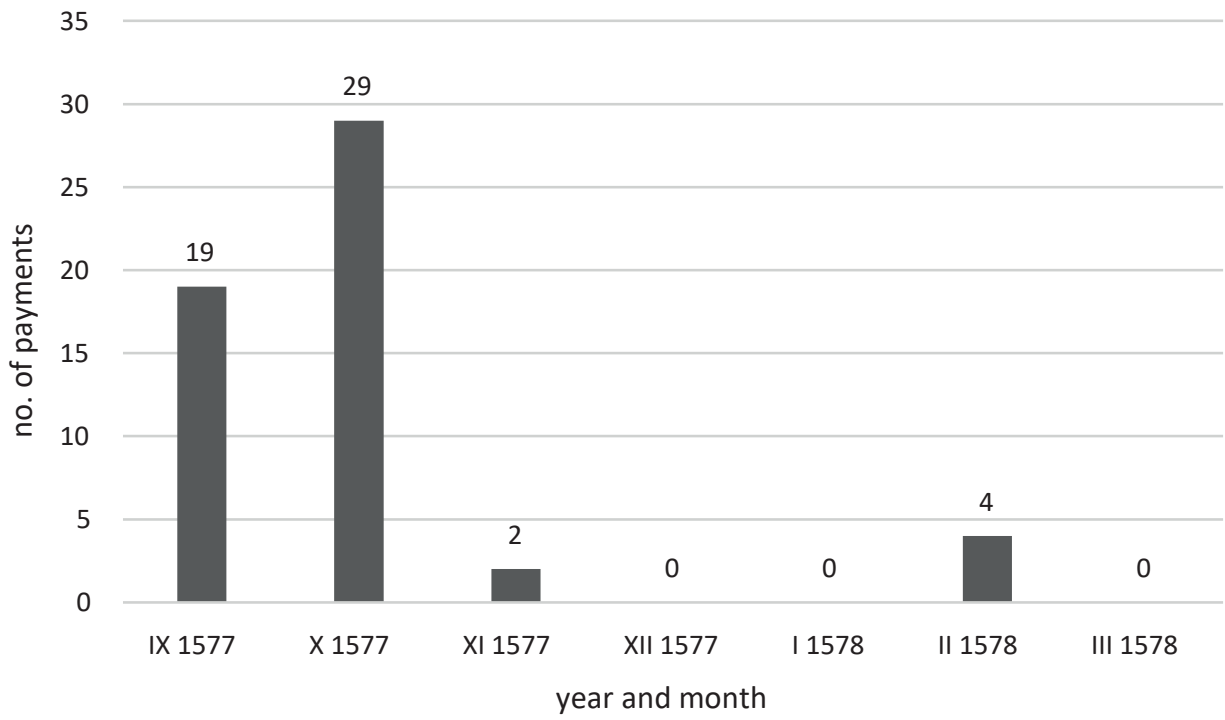

Fig. 10. The number of tax payments (by month) in Wschowa Land in 1577

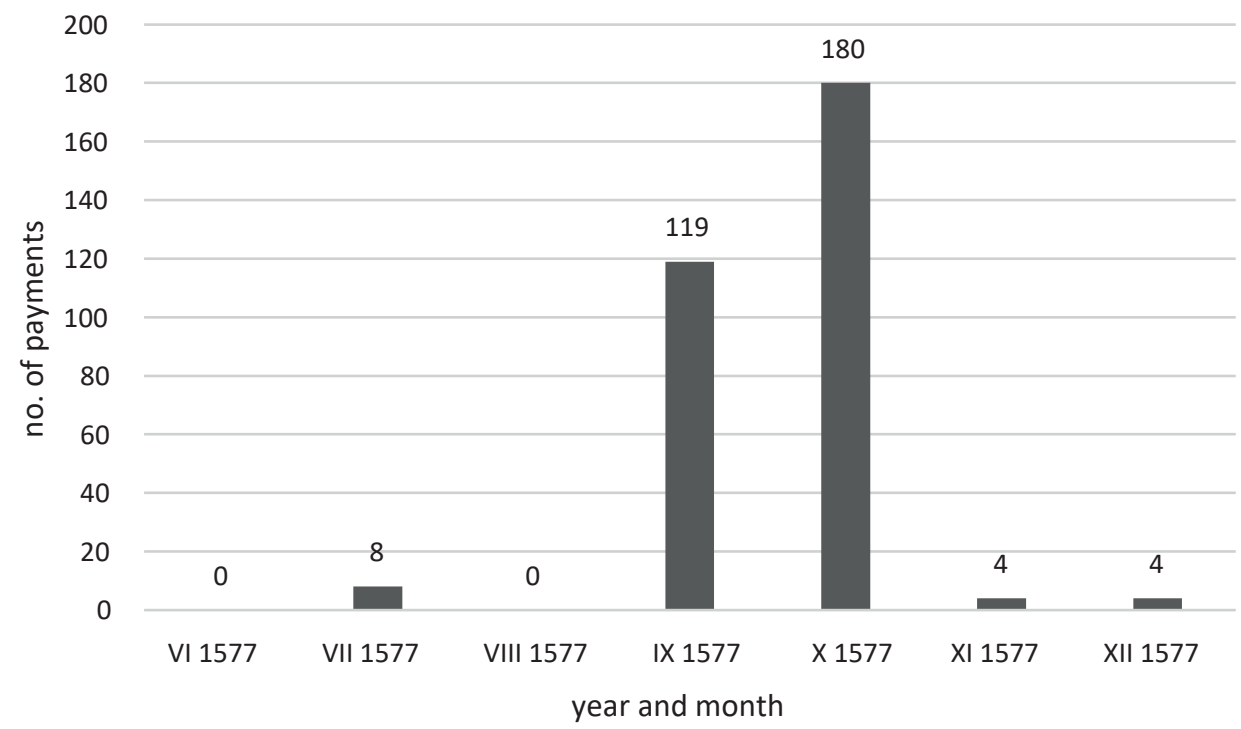

Fig. 11. The number of tax payments (by month) in Pyzdry District in 1577

\subsection{Identifying tax collectors}

While the general characteristic of the personnel responsible for tax collection has long been known, thanks in large part to the research of Adolf Pawiński in the nineteenth century, many issues connected 
with the topic remain unresolved. ${ }^{45}$ When it comes to persons performing functions for the Treasury, such as tax collectors, subcollectors, scribes, and stewards (Pol. szafarz, a person chosen by the Sejm or the local diet to receive revenue from tax collectors and distribute the money in accordance with the official purpose of the tax; see further in the text), the process of their selection, their social standing before and after their appointment, or their further careers remain largely a mystery. As such, we can only list some general observations made while studying tax registers, included below in the form of a simplified graph (Fig. 12). ${ }^{46}$

THE PLAIN STRUCTURE OF THE TAX COLLECTORS OFFICES

(CA. 1492-1613)

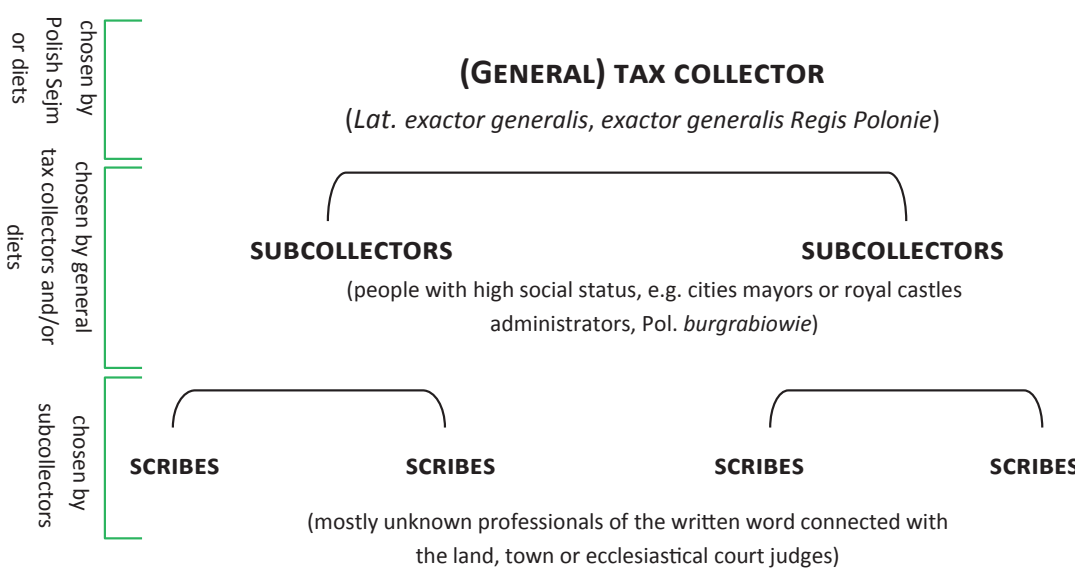

Fig. 12. The structure of the revenue system and tax collectors' offices in the Crown from the Late Middle Ages until the end of the sixteenth century; authors' own elaboration

The officials responsible for supervising collections in particular provinces were tax collectors (exactores), who were often listed by their name and surname in a tax uniwersat. In the Greater Poland of the fifteenth century, tax collections were conducted separately for Poznań and Kalisz Voivodeships. The exactor in Poznań Voivodeship was Stanisław Imbir from Objezierze (d. 1500), who performed the function of the castellan in Śrem (1494-1499). In Kalisz Voivodeship, the tax collector

45 A. Pawiński, op. cit., pp. 255-256, 261-264.

46 Tadeusz Szulc commented on the topic in his article "Sposoby wynagradzania poborców podatkowych w Polsce od schyłku XIV do XVIII wieku," Acta Universitatis Lodziensis. Folia Iuridica 56, 1993, pp. 91-106. 
was Jan Latalski (d. 1517), who performed the function of the royal castle administrator (Pol. burgrabia, Lat. burgrabius) of Gniezno from 1486 to 1493, and was a court justice in Kalisz in the period between 1495 and 1503; he also had held the title of the starost of Konin District during his career.

Another official whose name has survived was Jakub Boturzyński, Czewoja coat of arms (d. 1531), who in turn was the tax collector responsible for the whole province of Greater Poland, ${ }^{47}$ though he himself did not originally come from the region. He had already been performing his duties in 1506, which is evidenced, among other sources, by the receipts of Prince Sigismund Jagiellon, which confirm payments coming from the tariff revenue of the city of Poznan and other taxes. ${ }^{48}$ Boturzyński was also mentioned in tax registers: in the 1507 register from Kalisz as exactor Regie Maiestatis, ${ }^{49}$ and in 1508 as exactor generalis..$^{50} \mathrm{He}$ was also described as a tax collector and customs manager for Poznań (exactor et theloneator Posnaniensis), ${ }^{51}$ the Polish Royal Tax Collector (exactor Regis Poloniae), ${ }^{52}$ the tax collector for Greater Poland (exactor Maioris Poloniae), ${ }^{53}$ and, as it was noted for 1511, the tax collector for Kalisz District (exactor districtus Calisiensis).$^{54}$ In 1512 he was the Chief Customs Officer in Greater Poland. ${ }^{55}$

${ }^{47}$ In the 1480s, he sold his lands in Lesser Poland and moved to Greater Poland. His estates were located on the border of Pyzdry and Konin Districts. In 1493 he was listed as the royal castle administrator in Kraków, in 1505 he was a Member of the Parliament in the Poznań Sejm. He was also the tribune (Pol. wojski, Lat. tribunus) for Kalisz and Poznań. He died in 1531 and was buried in the Cistercian monastery in Lą, where his Renaissance-style tomb can be found today.

48 The Court Account Book of Sigismund Jagiellon (1504-1507), eds. K. Rábai, R.R. Trimonienè and P. Kasza, Szedeg, 2014, p. 53: "Myelnik 1506. Item [...] portati sunt per dominum Bothurzinski domino principi VIII C floreni in mediantibus Polonicalibus, florenum per $1 \frac{2}{2}$ sexagenam numerando, $\mathrm{V}$ C de theloneo Posnaniensi et III C de exartionibus [sic! - Authors] regalibus alias s poborow."

49 AGAD, ASK I 12, f. 1.

50 AGAD, ASK I 12, ff. 30, 61.

${ }^{51}$ Registrum dvořanů knížete a krále Zikmunda I. Jagellonského z let 1493-1510: mezi periferii a centrem jagellonského světa, eds. P. Kozák and K. Rábai, Opava, 2015 [?], p. 38.

${ }^{52}$ AGAD, ASK I 12 , f. $59 \mathrm{v}$.

53 AGAD, ASK I 12, f. 240. Cf. Matricularum Regni Poloniae summaria, vol. 4, ed. T. Wierzbowski, Warszawa 1917 (further: MRPS IV), no. 403 (=Crown Metrics (Metryka Koronna), archive division in The Central Archives of Historical Records in Warsaw (further: AGAD, MK) 23, p. 385).

${ }^{54}$ AGAD, ASK I 12, f. 146v.

55 MRPS IV, no. 1411 (=AGAD, MK 25, f. 118v); MRPS IV, no. 1412 (=AGAD, MK 25, f. 119v). 
On the basis of the collected information we could surmise that the main task of General Royal Tax Collector was supervising the collection of tax payments and coordinating with the Treasury. As such, the General Royal Tax Collector had certain prerogatives, among which was granting temporary amnesty from tax to a specific tax payer; however, evidence for this practice is quite elusive in the sources. In 1508, Bernard Gościejowski (Gosczyeyowski) and Bartłomiej Kołacki (Colacz$s k i)^{56}$ were exempt from tax due to their participation in the war with Moscow, ${ }^{57}$ and in 1510 a Kalisz townswoman, Katarzyna Skoczkowa, was exempt from paying the liquor tax of 10 florins. $^{58}$

The current state of research makes it impossible to ascertain whether the general tax collector first coordinated with the king or with the Royal Treasurer (Pol. Podskarbi, Lat. thesaurarius), as the currently available sources seem to suggest that at the turn of the fifteenth century the procedure was not clearly codified. While court receipts provide much evidence for the direct coordination with the king, this matter requires further study.

Other persons performing functions in the Treasury have fallen into an even greater obscurity. For example, Piotr Gunicki, an enigmatic official listed along with Jakub Boturzyński in $1510 .{ }^{59}$ He might have been a scribe managing the tax collector's correspondence, which is evidenced by the note in the royal receipts from 1508, in which he is mentioned as the royal secretary. ${ }^{60}$ Some names of subcollectors, directly responsible for the organisation of the collection in a given region, have survived: Teofil Tarnowski, the royal castle administrator in Pyzdry District, ${ }^{61}$ and Maciej Erazm, the long-time mayor and patrician in the city of Kalisz. ${ }^{62}$

Additionally, not much is known about the scribes directly responsible for the shape of the sources available today. During the analysis of the Kalisz District tax registers from years 1507 to 1510 , four authors could be distinguished (Fig. 13), out of which only one (scribe A) could be described as the chief scribe of the group. The only person

\footnotetext{
56 MRPS IV, no. 403 (=AGAD, MK 23, p. 385).

57 S. Herbst, "Wojna moskiewska 1507-1508," in: Ksiega pamiatkowa ku czci Oskara Haleckiego wydana w 25-lecie jego pracy naukowej, Warszawa, 1935, pp. 29-54.

${ }^{58}$ MRPS IV, no. 954 (=AGAD, MK 23, p. 793).

59 Volumina Constitutionum, vol. 1, part 1, p. 237.

${ }^{60}$ Registrum..., p. 340: "Petro Gunyczki notario regio ad Ia[cobum] Bothurzynski ad rationem thelonei novi ulne octo panni Florentini."

${ }^{61}$ AGAD, ASK I 11, p. 113.

${ }^{62}$ AGAD, ASK I 12, ff. 1, 30, 61, 91, 121
} 
identified by name was one of the scriveners for the consistory court in Kalisz, Andrzej Wyszanowski, ${ }^{63}$ who was a notary public of Imperial appointment in the Wrocław diocese while also performing the functions of a parson in Dobrzec Wielki near Kalisz, a canon in Sieradz, and a missionary in Kalisz. His name was listed in 1493 as a student at the University of Kraków. This person single-handedly recorded a quarter of all quit-rent payments in 1508 (not included in the table in Fig. 13).

\begin{tabular}{|l|c|c|c|c|}
\hline \multicolumn{1}{|c|}{ Scribe } & $\mathbf{1 5 0 7}$ & $\begin{array}{c}\mathbf{1 5 0 8} \\
(\boldsymbol{w a r} \boldsymbol{t a x})\end{array}$ & $\mathbf{1 5 0 9}$ & $\begin{array}{c}\mathbf{1 5 1 0} \\
\text { (first instalment) }\end{array}$ \\
\hline A & 484 & 416 & 353 & 339 \\
\hline B & 11 & 0 & 9 & 2 \\
\hline C & 31 & 0 & 1 & 0 \\
\hline D & 10 & 17 & 1 & 0 \\
\hline no data & 52 & 82 & 135 & 117 \\
\hline uncertain match & 13 & 3 & 0 & 3 \\
\hline
\end{tabular}

Fig. 13. The scribes who collectively compiled the tax registers in the years 1507-1510 in Kalisz District; authors' own elaboration

In the later periods, similarly to the arrangement from the fifteenth and sixteenth century, the personnel responsible for the collection of extraordinary taxes consisted of tax collectors, subcollectors, and Treasury scribes. Accounting taxes on the local level was the domain of a steward (szafarz) or deputies relegated by the local diet. For Greater Poland in the sixteenth century, usually one collector was appointed for each voivodeship, Poznań or Kalisz. In the case of three collections - in 1552, 1564, and 1565 - Kalisz Voivodeship was divided between two collectors. Moreover, the division did not always go along the same lines: in 1552, the tax from Konin, Kcynia and Pyzdry Districts was collected by a collector with the surname Rydzyński (first name unknown), while the districts of Nakło, Gniezno, and Kalisz fell under the jurisdiction of Dobrogost Potworowski. ${ }^{64}$ For the subsequent collection, agreed upon at the 1562-1563 Sejm session, a single tax collector was appointed

${ }^{63}$ We would like to thank Arkadiusz Borek for helping us in the identification of this individual.

${ }^{64}$ According to the uniwersat, Rydzyński was also supposed to collect the tax in Koło ("Colensis") District. No such district existed in Kalisz Voivodeship until the second half of the sixteenth century, though it might have been a reflection of earlier administrative divisions; Volumina Constitutionum, vol. 2, part 1, p. 40. 
for the entire voivodeship; ${ }^{65}$ however, the two following collections, in 1563-1564 and 1565, were divided again: Mikołaj Mileński collected the tax in Nakło, Kcynia, Gniezno, and Pyzdry Districts, while Maciej Starszewski did so in Konin and Kalisz Districts. ${ }^{66}$ While in 1552 the districts were divided evenly at three districts per collector, the selection of districts for each region is surprising, as they did not form consolidated areas. Rydzyński's jurisdiction encompassed Kcynia District, which is separated from Pyzdry and Konin Districts by Gniezno District; moreover, none of the districts under Dobrogost Potworowski's jurisdiction were adjacent to each other (Fig. 14).

The second division (1563-1564 and 1565) was much more pragmatic: the regions under Mikołaj Mileński and Maciej Starszewski's jurisdictions were consolidated and comprised neighbouring districts (Fig. 14). Exactly why there was such a disproportion in the number of districts - four falling under Mikołaj Mileński's jurisdiction and two under Maciej Starszewski's - remains unclear.

Tax collectors were also appointed by the local diets on the voivodeship level in Poznań and Kalisz Voivodeships. At the diet assembled in Sroda in March of 1573, held in preparation for the upcoming Sejm, Dobrogost Sobocki was appointed tax collector for Poznań Voivodeship, while Mikołaj Głogiński was given that role in Kalisz Voivodeship. ${ }^{67}$ At the post-Sejm diet assembly in Środa in 1593, Andrzej Obornicki was appointed tax collector in Poznań and Kacper Modlibowski in Kalisz. ${ }^{68}$ Appointments to the function of tax collector were made especially when it was the sejmik which decided on tax collection, as was the case of the general diet assembly in Koło in 1577 (with Jan Sławski chosen for Poznań and Mikołaj Głogiński for Kalisz Voivodeship) or the deputational diet assembly in Środa in 1596 (Adam Naramowski for Poznań and Jan Byszewski for Kalisz). ${ }^{69}$

${ }^{65}$ A uniwersat would not contain a list of collectors at that time. Wojciech Marszewski of Kalisz Voivodeship was noted down in the Treasury documentation, as he had commissioned the incorporation of the tax arrears list into the town records of the district in 1563, which indicates that he was a collector or subcollector. At that time, Jakub Rokossowski was the tax collector in Poznań Voivodeship; AGAD, ASK I 11, p. 771; RPWP, wlc, 1563; AGAD, ASK I 5, f. 203; RPWP, pzn, 1563; AGAD, ASK I 5, f. 211; AGAD, ASK I 5, ksc, 1563; AGAD, ASK I 4, f. 140; AGAD, ASK I 4, wch, 1563; AGAD, ASK I 5, f. 204.

${ }_{66}$ Volumina Constitutionum, vol. 2, part 1, p. 151.

${ }^{67}$ ASWPK, p. 10.

${ }^{68}$ ASWPK, p. 172.

69 ASWPK, pp. 29, 185. 

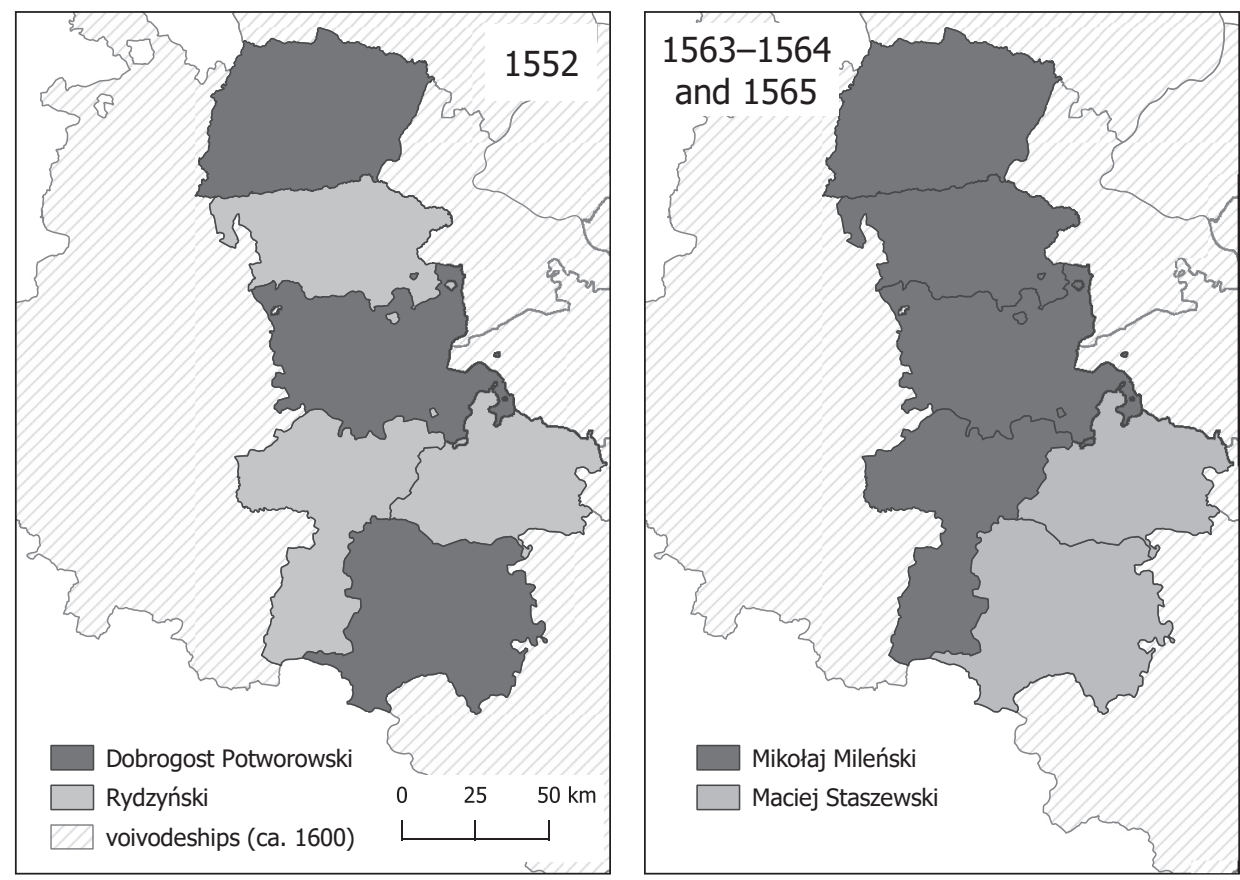

Fig. 14. The division of Kalisz Voivodeship between tax collectors Dobrogost Potworowski and Rydzyński in 1552 and Mikołaj Mileńki and Maciej Staszewski in 1563-1564 and 1565

As mentioned earlier, the tax collector did not conduct the collection on their own, but with the help of subcollectors and scribes. In the situation such as the aforementioned division of Kalisz Voivodeship, there was no need for the collector to reside in the district during the collection; instead, deputised subcollectors were appointed for every region.

The procedure for appointing subcollectors remains yet to be thoroughly researched. It seems that the choice might have been left solely at the discretion of the collectors. Resolutions made at the diet assemblies in Greater Poland certainly seem to suggest that. While towards the end of the sixteenth century and the beginning of the seventeenth century collectors were regularly appointed at diet assemblies in Środa, the same could not be said for subcollectors. For that period, only once was the appointment of subcollectors mentioned in the assembly documents, those produced at the diet in Sroda on the $29^{\text {th }}$ of December 1587. The members of the nobility assembled in Środa appointed subcollectors for Kalisz Voivodeship: Jan Cielecki for Kalisz District, Stanisław Wolicki for Konin District, Krzysztof Bardzki for Pyzdry 
District, Sebastian Żydowski for Gniezno, and Stanisław Zebrzydowski for Nakło and Kcynia. ${ }^{70}$ Interestingly, receipts from the accounting of the tax money, perhaps with the tax collector of the voivodeship, brought in by these subcollectors have survived in the Archives of the Crown Treasury (Fig. 15). ${ }^{71}$

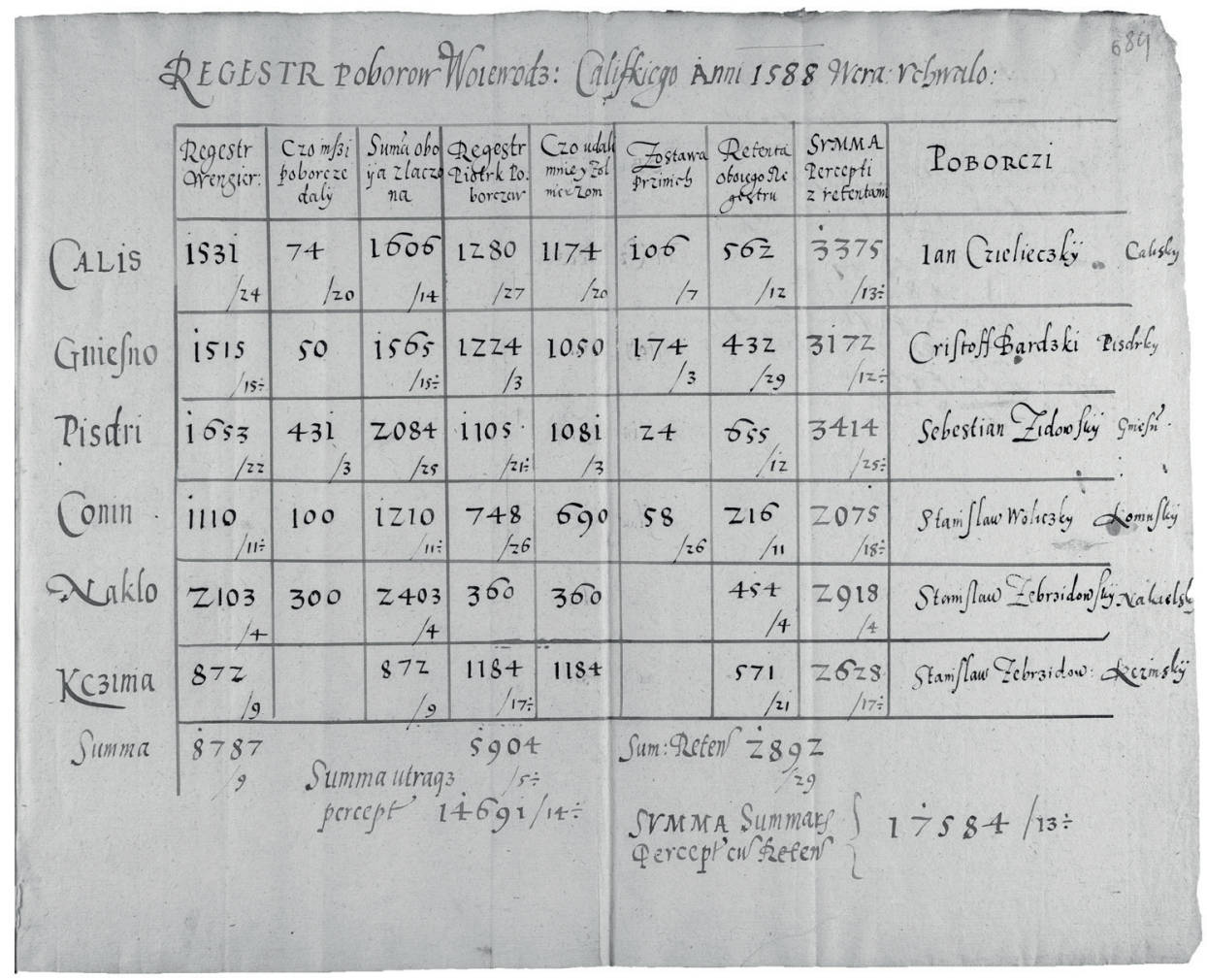

Fig. 15. The account of payments collected by subcollectors in districts of Kalisz Voivodeship in 1588; AGAD, ASK I 11, p. 684

In the same diet's resolution, Jan Cielecki, the subcollector for Kalisz District, was made General Tax Collector in place of Mateusz Węgierski. The document was also specified that "the tax collector for Poznań shall reside in Poznań, and the tax collector for Kalisz - in Kalisz."72 For Poznań Voivodeship, only the General Tax Collector was chosen, without the appointment of any subcollectors.

\footnotetext{
70 ASWPK, p. 72.

${ }^{71}$ AGAD, ASK I 11, p. 684.

72 ASWPK, p. 72.
} 
In the second half of the sixteenth century, specifically in 1582 , there were instances of members of the bourgeoisie being appointed to official functions. In Poznań District, the appointed subcollector was Adam Borek, a pharmacist, most likely from Poznań, and in Wschowa Land, a burgher by the name of Michał Fetter. The information comes from the lists of tax arrears, which were recorded by the aforementioned burghers in starost court books in their respective districts. ${ }^{73}$

Similarly to the state of affairs in the previous period, the information on the scribes is scarce. They are omitted from sources and never mentioned in either uniwersaty or the diet documents. Scraps of information can be found in Treasury documents, which sometimes include their signatures, as in the case of scribe Walenty Krzepicki, the author of the Nakło District tax register from $1578 .{ }^{74}$

The same register features signatures of two other people - Rafal Leszczyński, the castellan of Radziejów, and Hieronim Bużeński, the castellan of Sieradz. ${ }^{75}$ Both held functions important in the final stages of the collection of extraordinary taxes - the steward (szafarz) and the deputy. Rafał Leszczyński's appointment to the function of a steward was decided by the Sejm. Under the provisions of the uniwersat, he supervised the collection of tax in the whole province of Greater Poland, that is in Poznań, Kalisz, Łęczyca, Brześć Kujawski, Inowrocław, and Sieradz Voivodeships, as well as the separately-mentioned Wielun Land (which was located within the borders of Sieradz Voivodeship) and Dobrzyń Land. ${ }^{76}$

The royal steward's role was to account and receive the tax revenue from the tax collectors. Depending on the tax collection, their task might have been to either deliver the income to the Royal Treasury, or use it according to its premeditated objective, usually for military purposes. ${ }^{77}$ Under the uniwersat of 1567 , the royal administrators were to be supervised by the voivodes or castellans. ${ }^{78}$

The territories under the stewards' jurisdiction had changed across time. In 1567, almost all voivodeships had its own szafarz; the aforementioned Rafał Leszczyński performed the function in Kalisz Voivodeship. ${ }^{79}$ In 1578 , several voivodeships could be supervised by

\footnotetext{
${ }^{73}$ AGAD, ASK I 6, p. 27; AGAD, ASK I 3, p. 660.

${ }^{74}$ RPWK, nkl, 1578; AGAD, ASK I 5, p. 838v.

75 RPWK, nkl, 1578; AGAD, ASK I 5, p. 838v..

76 Volumina Constitutionum, vol. 2, part 1, p. 429.

77 A. Pawiński, op. cit., pp. 262-264.

78 Volumina Constitutionum, vol. 2, part 1, pp. 210-212.

${ }^{79}$ Ibid., p. 211.
} 
a single szafarz, and in 1581 only two were assigned for the whole Crown - one to oversee collections, and one to issue pay to the soldiers. ${ }^{80}$ Sejmik assemblies also appointed people to the function of a $s z a$ farz, either to fulfil the resolutions issued by the Sejm, or following an independent decision to introduce tax collection in the region. Greater Poland saw an example of the former in 1593, when it was decreed in the uniwersat issued by the Sejm that Poznan and Kalisz Voivodeships should appoint stewards at the local diet; ${ }^{81}$ during the following assembly in Środa in 1593, Jan Gajewski (Poznań) and Stanisław Chłapowski (Kalisz) were appointed to the function of a szafarz. ${ }^{82}$ An example of the sejmik in Środa appointing officials on its own initiative came in September of 1596, when Marcin Padniewski and Jan Orzelski were elected stewards. ${ }^{83}$

The aforementioned Hieronim Bużyński, the castellan of Sieradz, left his signature "by his own hand" in the Nakło tax register in 1578 as the "deputy for the tax accounting [officer] in Greater Poland." ${ }^{44}$ Similarly as in the case of the scribes, few sources remain that would help identify the deputies for tax accounting. Their sejmik-issued role was supposed to involve settling accounts with the tax collectors or szafarze, or at least this was the task given to the deputies at the diet in Sroda in December 1587. The decision was made to choose the deputies after the coronation Sejm. ${ }^{85}$ The selection of deputies, their position within the nobility, and their responsibilities require further studies.

\subsection{Accounting overdue taxes}

It was inevitable that some towns and villages in the Crown would eventually not be able to meet due payments for their taxes. Lists of towns and villages who had for various reasons accrued debt from tax arrears are known in the literature of the subject as "retenty"; 86 such lists were evidently required to be included in the tax documentation compiled for the Royal Treasury officials. It was especially true

\footnotetext{
80 Ibid., p. 462.

81 Ibid., p. 340.

${ }^{82}$ ASWPK, p. 172.

${ }^{83}$ ASWPK, p. 185.

${ }^{84}$ AGAD, ASK I 5, p. 838v

${ }^{85}$ We don't know when, or if at all, the post-Sejm sejmik assembly took place. ASWPK, p. 72.

${ }^{86}$ The word has its roots in Latin (retentare) and means "to hold back, restrain," but also "to keep in memory." See also: A. Pawiński, op. cit., pp. 283-285.
} 
for cases in which tax arrears were penalised; a village which lagged behind in payment at the turn of the fifteenth century faced a fine of 14 marcs (Lat. marca, Pol. grzywna, a unit of account; one marc was usually 48 groshes).

While in the second half of the sixteenth century we can observe a separate lists of tax arrears circulating in tax documentation together with registers and recognitiones, no such documents could be found for earlier periods. Because collection of taxes that were not paid within due time was strictly the domain of the local starost and their officials (mainly royal castle administrators), it comes as little surprise that it was common practice to list villages with arrears for non-payment of taxes in starost court books. ${ }^{87}$

These lists of tax arrears undoubtedly require a separate study. We could, however, attempt to briefly analyse some of the sources. One of them is a list of towns and villages from $1499,{ }^{88}$ a year in which the January and February Sejm announced the introduction of two extraordinary taxes - a liquor tax and a land tax (kanowe); ${ }^{89} 144$ towns and villages (divided into six separate entries) are listed as having outstanding taxes in the starost court book. The first note was made towards the end of April, while the last one is dated for the beginning of July of 1499. Twelve villages are listed in the register more than once; the most towns and villages with overdue taxes (64) were noted down in the starost court book on the $29^{\text {th }}$ of April 1499, while the least in the fifth note, was dated the $3^{\text {rd }}$ of June 1499.

Most villages on tax arrears lists appear there only once, only twelve villages were listed twice or even thrice. Two factors need to be considered in the interpretation of this phenomenon, the first being the ownership of the land. It was often the case that singular villages were divided among several landlords, with different manorial divisions (sortes) scattered within one village; there were also numerous hamlets (Pol. przysiótki) orbiting the main settlements in a rather spatially unstructured manner. ${ }^{90}$ The analysis of the selling, buying, and renting of villages in the Late Middle Ages and the early modern period clearly shows that village ownership was a complex, dynamic matter

${ }^{87}$ In Kalisz court records (AP Poznań, Kalisz Gr. 29, 30, and 31) 30 such entries could be found.

${ }^{88}$ AP Poznań, Kalisz Gr. 30, ff. 53r, 54r, 54v-55r, 59r-59v, 61r, 64r-64v.

89 Volumina Constitutionum, vol. 1, part 1, pp. 91, 93-94.

${ }_{90}$ Besides the well-preserved libri resignationum for Greater Poland, a great deal of information on the topic can be inferred from the quarter tax from quit-rent on villages recorded in 1508. See: AGAD, ASK I 12, ff. 30v-59v (for Kalisz District). 
that could be subject to change within the passage of a relatively short time. ${ }^{91}$ As such, the villages appearing twice or thrice in tax arrears lists should be interpreted as different manorial divisions with overdue tax payments within one village.

Evidence for this conclusion can be seen in the repercussions for outstanding taxes, as court books are clear on the penalty for not meeting the payments - 14 grzywny of silver as "repercussionis pignorum ob non solucionem fertonum exaccionis regie et czopowe."92 Interestingly enough, the fine did not increase with further delays in other tax payments (in 1499 it was a land tax and a liquor tax) and had the form of a lump-sum payment.

The data extracted from court books allows for the analysis of the spatial distribution of the villages on tax arrears lists (Fig. 16). For example, on the basis of the 1499 tax arrears list for Kalisz District, certain patterns related to the execution of tax payments become apparent. The system established by the starost's office evidently grouped villages according to both proximity and ownership. Both elements went hand in hand at the beginning of the sixteenth century, as the wealthier peasants and nobility bringing in tax money to the district seat very often made payments on specific property (in its entirety or in part). In the fourth entry in the tax arrears list, the villages of Chodupki, Koźminek, Nakwasin, Osuchów, Skalmierzyce, Smółki, and Złotniki Wielkie were annotated as "villa domini Poznaniensis" (a village belonging to the castellan of Poznań). ${ }^{93}$ It is assumed that the duty to confirm payment belonged to court bailiffs, who would have to visit the villages; grouping the villages according to specific patterns served to facilitate the bailiffs' work, which can be seen in the form of routes - blue, red, and yellow - on the map below. Naturally, to prove or disprove those claims, further analysis of starost court books, not only of Kalisz District but also from neighbouring regions, is required.

Numerous tax arrears lists from the second half of the sixteenth century have also survived until today, ${ }^{94}$ including several tax arrears registers (regestra retentorum) for Poznań Voivodeship: from 1579 and

${ }^{91}$ A. Pośpiech, "Księgi rezygnacji w kaliskich aktach grodzkich z lat 1580-1655. Prezentacja źródła, możliwości badawcze,” Rocznik Kaliski 21, 1989, pp. 19-49.

${ }^{92}$ AP Poznań, Kalisz Gr. 30, f. 53r.

${ }^{93}$ Ibid., f. 59v.

${ }_{94}$ However, it should be mentioned that while initially the tax arrears lists were incorporated into town records and, according to our current state of knowledge, no separate libri retentorum existed at the time, in the second part of the sixteenth century separate lists became a standard, along with entries in the town records. 


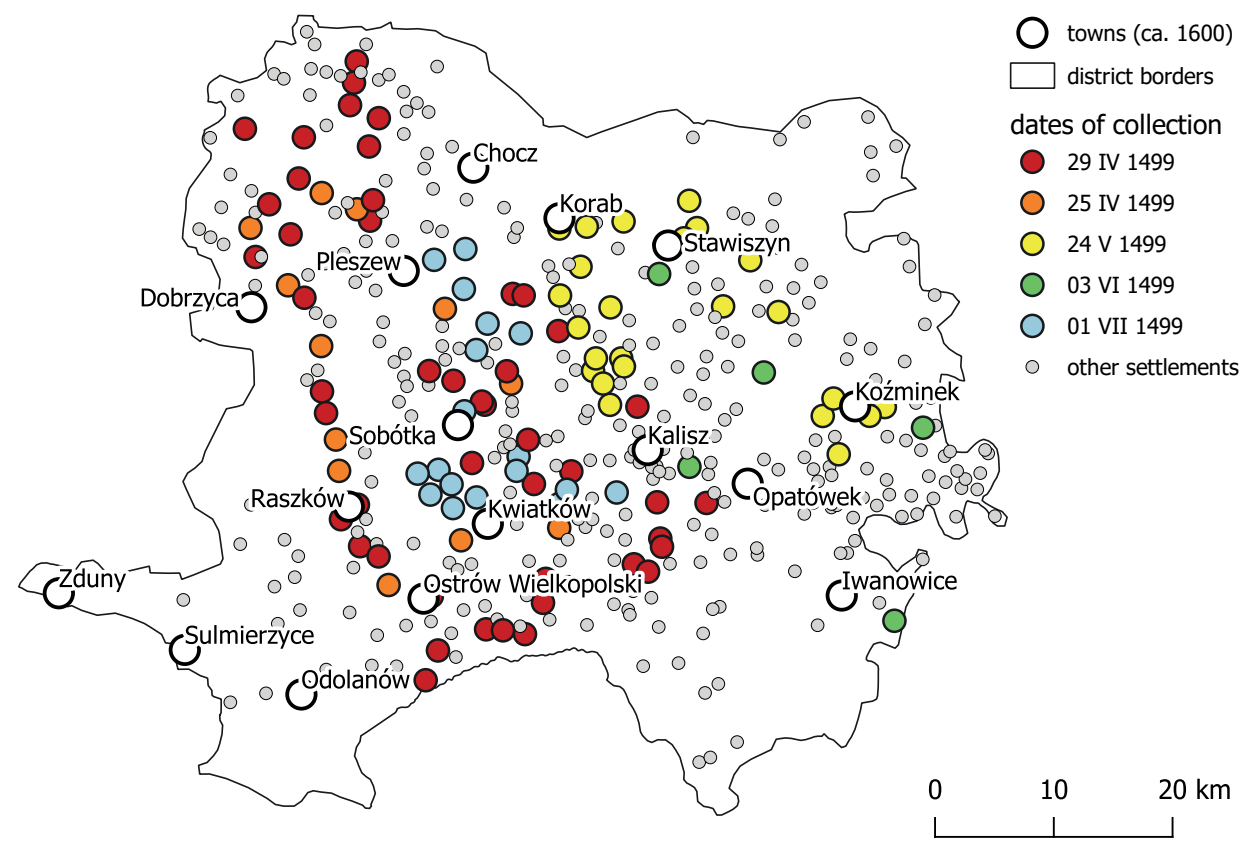

Fig. 16. Collection of the overdue taxes in 1499 on the basis of starost court books; AP Poznań, Kalisz Gr. 30; authors' own elaboration

1580 for Wschowa Land, from 1581 and 1582 for Poznań and Kalisz Districts. ${ }^{95}$ While the analysis of all of these sources could fill a whole other study, we will briefly take a look at the two registers concerning Poznań District.

The 1581 tax arrears list was compiled by collating the current tax register and the list of payments in the 1578 register. In other words, after collecting payments and putting them on a register, the subcollector compared this list with an older register, then noted the disparity in the number of entries (of particular tax categories) and compiled a list of tax arrears on that basis. The register for the year 1578 was probably chosen because in that year tax collection was conducted according to the so-called "new receipts" (Pol. nowe kwity), which were the new and actual tax returns, serving as insurance that the status of the tax base was up to date. ${ }^{96}$ The tax register for the year 1578 became the reference for tax inspection in the following years.

95 AGAD, ASK I 3, ff. 656v-660, 702-738; AGAD, ASK I 4, ff. 561-575v, 598-615v; AGAD, ASK I 6, ff. 1-27.

${ }^{96}$ Volumina Constitutionum, vol. 1, part 1, pp. 421-430. 
The tax arrears list was officially incorporated into the starost court books of Poznan District, which took place on the $19^{\text {th }}$ of June 1582, which is certainly thought-provoking. Payment dates in the tax register for Poznan District in 1581 show that most of them were made in April (363 entries), and May (374 entries) of 1581, while only four payments were booked in June, and 141 entries were not dated at all. The tax was almost entirely collected within its intended time frame, from the release of the uniwersat on the $6^{\text {th }}$ of March 1581 to the $14^{\text {th }}$ of May of that year. ${ }^{97}$ There is thus a year-long gap between the due date of the tax and the entry of the tax arrears list into the starost court book. The delay might have been caused by the lack of the 1578 tax register on hand, which had to be procured for comparison, for example from the Crown Treasury; however, no tax register for 1578 has survived in the Archives of the Crown Treasury, which points to the starost court office in Poznan as the possible place where such a document could have been stored. Unfortunately, the current state of research does not allow for a good explanation of why the subcollector delayed the recording of list of tax arrears in the starost court books.

Also unknown is the identity of the subcollector for Poznan District at the time; however, it was certainly the same person who had recorded the tax arrears list in 1582 . The register was then copied by the starost court scriveners, provided with an official seal (with the Eodzia coat of arms, the coat of arms of the General Starost of Greater Poland, Andrzej Opaliński ${ }^{98}$ ), as well as the signatures of Wojciech Zajączkowski, the deputy of the starost court judge of Poznan District (iudex surrogatus castrensis Posnaniensis) and Dobiesław Przyborowski, the starost court scribe of Poznan District (Fig. 17). At the bottom of the manuscript page is the sum of tax arrears for the whole register - 1,043 florins, 12 groshes, and 12 denarii, with the note that the sum contains outstanding taxes for distillation and excise of liquor (118 florins and 19 groshes). The same scribe accounted all sums on the other pages of the register. ${ }^{99}$

Handwriting analysis of the register reveals that the subcollector wanted the certified copy as soon as possible. Four hands can be distinguished: the first one (scribe A) wrote entries on pages $702-713 \mathrm{v}$ and 738 (24 pages), and supplied the register with a title page and the

97 Volumina Constitutionum, vol. 2, part 1, p. 463.

98 A. Bieniaszewski, op. cit., p. 220.

${ }_{99}$ AGAD, ASK I 3, f. 738. The same person also wrote down the sums in the 1581 and 1582 tax arrears lists for Kościan District; AGAD, ASK I 4, ff. 575, 615. 


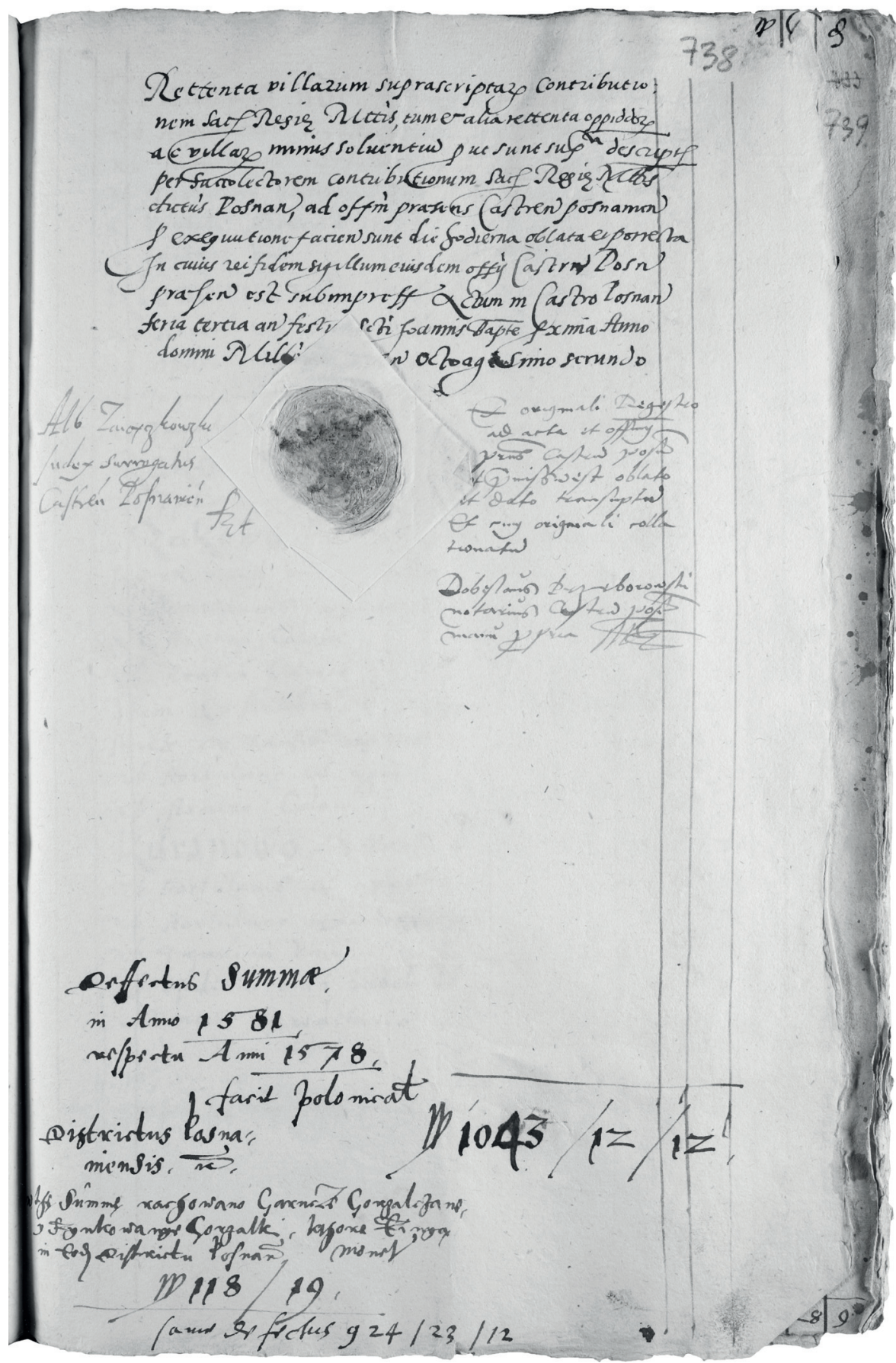

Fig. 17. The last page of the 1581 tax arrears list for Poznan District; AGAD, ASK I 3, f. 738 
afterword informing of the official tax arrears list recording in the register; the second hand (scribe B) we find on pages 714-724v (22 pages); the third hand (scribe C) authored pages 725-732v (14 pages); the last scribe (D) compiled the part of the register concerning the number of mills around the city of Poznan and the list of towns (pages 733-737v, 10 pages altogether). The workload was thus divided between four scribes, the first two having been given fairly equal amounts of work, the fourth being tasked with compiling a consistent list of mills and towns, and the third scribe wrapping up any leftover work on the register.

The large majority of the entries in the register concerns small sums originating from multiple taxes (one to two mansus field owners and cotters, sometimes landless peasantry, singular waterwheels, small-scale liquor production, etc.). Ultimately, for 698 towns and villages enumerated in the tax register, $456(65 \%)$ were also mentioned in the tax arrears list; however, the sum of all tax arrears amounted to just 1,043 florins, 12 groshes, and 12 denarii, which constituted only $13 \%$ of the overall sum of taxes paid according to the tax register $(7,923$ florins, 21 groshes, 3 denarii). Tax arrears for that year were therefore not excessive; while some irregularities could be suspected to stem from forgeries, changes in the tax base could account for a good amount of outstanding tax. ${ }^{100}$

A somewhat similar situation concerning overdue tax emerged a year later - this list of tax arrears was also compiled against the 1578 tax register, and it also lists small amounts in unpaid taxes in numerous villages. The date of the recording of this list in the starost court books remains unknown, although, similarly to the situation from 1581, the copy was authenticated by Wojciech Zajączkowski and Dobiesław Przyborowski, and provided with a seal (this one is unfortunately covered with small scraps of paper, but there is a good probability that it is identical to the one from 1581); additional signatures were provided by the subcollector Adam Borek, a pharmacist from Poznan, and another person who might have been the tax collector for Kalisz District at the time, Jan Gajewski, though difficulties in interpretation make it impossible to rule out all other possible signatories. ${ }^{101}$ As opposed to the 1581 register, the 1582 tax arrears list was compiled in its entirety by a single scribe (barring sums at the bottoms of the pages), the same hand that had summed up the amounts in the 1581 register.

100 Cf. K. Górska, "Przyczynek do krytyki rejestrów poborowych z XVI wieku," St. Źródt. 1, 1957, pp. 185-189.

${ }^{101}$ AGAD, ASK I 6, f. 27. 
Since the 1582 tax register has not survived, we can only compare the 1582 tax arrears list to the tax registers from 1581 and 1583. In the case of the former, the tax arrears list in 1582 mentions $58 \%$ of all towns and villages (404 out of 698), while in comparison with 1583 it would have been $57 \%$ (404 out of 708 towns and villages). The amount of tax arrears (409 florins and 6 groshes) in comparison with both tax registers was just 5\% (7,923 florins 21 groshes and 3 denarii in 1581, and 7,551 florins 22 groshes and 3 denarii in 1583; Fig. 18).

\begin{tabular}{|l|c|c|}
\hline \multicolumn{1}{|c|}{ Source } & $\begin{array}{c}\text { Number } \\
\text { of villages }\end{array}$ & $\begin{array}{c}\text { Tax revenue } \\
\text { in florins }\end{array}$ \\
\hline 1581 tax register for Poznań District & 698 & 7,923 \\
\hline 1581 list of tax arrears for Poznań District & 456 & 1,043 \\
\hline Percentage & $65 \%$ & $13 \%$ \\
\hline 1581 tax register for Poznań District & 698 & 7,923 \\
\hline 1582 list of tax arrears for Poznań District & 404 & 409 \\
\hline Percentage & $58 \%$ & $5 \%$ \\
\hline 1583 tax register for Poznań District & 708 & 7,551 \\
\hline 1582 list of tax arrears for Poznań District & 404 & 409 \\
\hline Percentage & $57 \%$ & $5 \%$ \\
\hline
\end{tabular}

Fig. 18. Comparison of the number of villages, the sum of all due taxes, and the sum of overdue taxes in Poznań District in years 1581-1583; authors' own elaboration

\subsection{State and administrative inclusion of towns and villages}

In the case of Greater Poland of the sixteenth century, the usual procedure was to compile tax registers on payments from towns and villages from a single district. The rule seems to have been the norm in the whole of the Crown, though in practice much depended on the region; in Podlasie, for example, which lay at the border of the Crown and the Great Lithuanian Duchy, tax registers were made to account for lands. ${ }^{102}$ As such, tax registers used as historical sources play a significant role in the reconstruction of the administrative borders of the state; for example, they have found use in the compilation of the Historical Atlas of Poland. ${ }^{103}$ However, fiscal district borders reconstructed on the

102 Cf. I. Gieysztorowa, "Mazowieckie akta skarbowe XV-XVII w.: próba odtworzenia układu," in: Ksiega pamiatkowa 150-lecia Archiwum Głównego Akt Dawnych $w$ Warszawie, ed. A. Stebelski, Warszawa, 1958, pp. 209-217.

${ }^{103}$ H. Rutkowski, "Granice państwowych jednostek terytorialnych," in: Województwo krakowskie w drugiej połowie XVI wieku, ed. H. Rutkowski, Warszawa, 2008, 
basis of tax registers did not always perfectly mirror the shape of court districts. A well-documented case for the contrary is the existence of the fiscal districts of Proszów and Szczyrzyc in Kraków Voivodeship. The Proszów fiscal district encompassed the territory of the Proszów court district as well as the northern part of the Kraków court district, while the Szczyrzyc fiscal district consisted of the southern part of the Kraków court district. ${ }^{104}$

In Greater Poland the phenomenon manifested itself only in the case of Wałcz District. In the sixteenth century a separate court district for Wałcz did not exist, there was only a separate fiscal district. In $1554 \mathrm{Wałcz}$ became the seat of a starost court district (Pol. starostwo grodowe, roughly equivalent to a borough), which probably took the shape of the existing fiscal district. ${ }^{105}$

In many cases settlements located on the border of two districts cannot be indisputably placed on administrative maps on the basis of tax registers, as the district in which the tax payments from these border settlements were booked often changed; Kuślin, ${ }^{106}$ Lutol Wodny, ${ }^{107}$ Rogoziniec, ${ }^{108}$ Wassowo $^{109}$ - all villages on the border of Poznań and Kościan Districts - can serve as examples of this phenomenon (see Fig. 19).

When assessing the usefulness of tax registers in establishing historical borders, two factors need to be taken into consideration: the pattern that the source followed and the actual place where the tax was paid.

pp. 28-29 (Atlas historyczny Polski. Mapy szczegółowe XVI wieku, vol. 1); English version: H. Rutkowski, "Cracow Voivodeship," in: Historical Atlas of Poland in the $2^{\text {nd }}$ Half of the $16^{\text {th }}$ Century. Voivodeships of Cracow, Sandomierz, Lublin, Sieradz, Eęczyca, Rawa, Płock and Mazovia, eds. Marek Słoń, Peter Lang 2014, pp. 126-129.

${ }^{104}$ H. Rutkowski, "Granice...," pp. 27-35; id., "Cracow...," pp. 124-137.

105 J. Bielecka, "Sąd grodzki w Wałczu," Roczniki Historyczne 26, 1960, pp. 265-271.

106 RPWP, ksc, 1563, no. 380; RPWP, ksc, 1565, no. 266; RPWP, ksc, 1567, no. 47; RPWP, ksc, 1576, no. 393; RPWP, ksc, 1580, no. 431; RPWP, pzn, 1576, no. 328; RPWP, pzn, 1577, no. 358; RPWP, pzn, 1580, no. 361; RPWP, pzn, 1581, no. 359; RPWP, pzn, 1583 , no. 367.

${ }^{107}$ RPWP, pzn, 1567, no. 506; RPWP, pzn, 1570, no. 37; RPWP, pzn, 1576, no. 315; RPWP, pzn, 1577, no. 345; RPWP, pzn, 1580, no. 349; RPWP, pzn, 1583, no. 354; RPWP, ksc, 1563, no. 599; RPWP, ksc, 1565, no. 604; RPWP, ksc, 1576, no. 615; RPWP, ksc, 1580, no. 768; RPWP, ksc, 1581, no. 534; RPWP, ksc, 1583, no. 597.

108 RPWP, pzn, 1553, no. 402; RPWP, pzn, 1567, no. 332; RPWP, pzn, 1576, no. 484; RPWP, pzn, 1577, no. 528; RPWP, pzn, 1583, no. 547; RPWP, ksc, 1563, no. 155; RPWP, ksc, 1565, no. 157; RPWP, ksc, 1576, no. 155; RPWP, ksc, 1580, no. 595.

109 RPWP, pzn, 1553, no. 538; RPWP, pzn, 1563, no. 672; RPWP, pzn, 1576, no. 661; RPWP, pzn, 1577, no. 702; RPWP, pzn, 1580, no. 741; RPWP, pzn, 1581, no. 730; RPWP, pzn, 1583, no. 745; RPWP, ksc, 1563, no. 658; RPWP, ksc, 1565, no. 663 ; RPWP, ksc, 1576, 682. 


\begin{tabular}{|l|l|l|}
\hline $\begin{array}{c}\text { Settlement } \\
\text { Name }\end{array}$ & $\begin{array}{c}\text { Tax Registers of Poznań District } \\
\text { [years] }\end{array}$ & $\begin{array}{c}\text { Tax Registers of Kościan District } \\
\text { [years] }\end{array}$ \\
\hline Kuślin & $1567,1576,1577,1580,1581,1583$ & $1563,1565,1567,1576$ \\
\hline Lutol Wodny & $1567,1570,1576,1577$ & $1563,1565,1576,1580,1581,1583$ \\
\hline Rogoziniec & $1553,1567,1576,1577,1583$ & $1563,1565,1576$ i 1580 \\
\hline Wąsowo & $\begin{array}{l}1553,1563,1576,1577,1580,1581, \\
1583\end{array}$ & $1563,1565,1576$ \\
\hline
\end{tabular}

Fig. 19. Tax registers of Poznań and Kościan Districts (by year) in which tax payments from listed settlements were made

The former concerned the creation of a basis for a tax register and the preparation for entering the payments. It seems like the tax collectors and their co-workers utilised previously-compiled registers to compile lists of towns and villages where the tax should be paid. An example can be the 1591 tax register from the Nakło District, which mostly (126 villages of 186 listed in the register) consists of just headers with the name of the village; the information on payments was ultimately not entered into the register (Fig. 20).

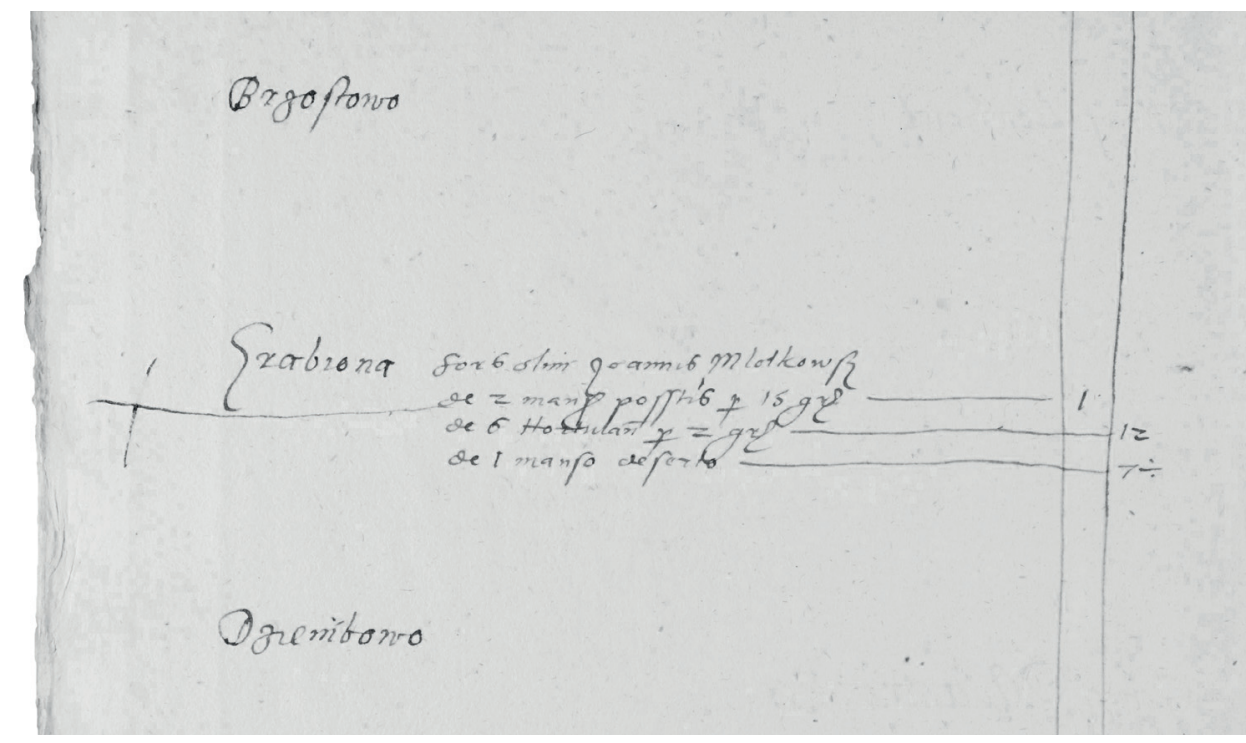

Fig. 20. A fragment of the 1591 tax register from Nakło District; in the case of this page, note of payment was made only for the village of Grabionna; AGAD, ASK I 4, f. 761v

Similarly, earlier registers were utilised to verify tax payments and as help in listing debtors with outstanding tax (with either the whole or a part of the payment missing). As a consequence, if one village 
appeared in one of the registers, it was usually copied in the consecutive registers for the district. If a tax was paid for such a settlement, the payment was entered, and if no payment came, a blank space was left or it was noted that the payment had not been made. The list of towns and villages that served as the basis for a tax register was not usually updated unless new settlements emerged in the district. ${ }^{110}$ As noted by Gieysztorowa, the revenue system was essentially conservative, which served to preserve past information about the town or village, its factual administrative affiliation or any other change in that regard. ${ }^{111}$

The second factor in the reconstruction of borders is the actual place where payments were made by the taxpayers. In the sixteenth century the tax collectors usually established their offices in the district seat, where taxpayers had to venture from all over the district. Oftentimes landowners held properties in multiple districts and in theory should have paid the tax separately for each of their properties in each district. As a general rule, this was how the tax payments were booked in registers in Greater Poland of the second half of the sixteenth century. However, in some instances taxes were paid to only one tax collector, which meant that no payments were booked in the tax registers in other districts, or a note was made that the tax had been paid elsewhere. The Kościan District tax registers from 1563 and 1565 constitute an interesting example of this phenomenon.

In the case of the 1563 tax register, some entries were accompanied by a note that the tax had been paid in Poznan District (most often worded as "solvit Poznaniae" - "paid in Poznań"), though all tax categories were listed along with the sum paid, which meant that the taxpayers had already paid their dues and only presented the receipt to the subcollector in Kościan, which was then used to create the entry in the tax register. Despite the reason for the annotation, it did not mean that the village was part of Poznan District. Close analysis of this and other Kościan District registers allows for a conclusion that it was only payment information, not the evidence for the village's placement in Poznań District. ${ }^{12}$ The Kościan District from the 1563 tax

${ }^{110}$ Cf. tax registers for Nakło District, where for years 1578, 1579, 1581 and 1582 there is a special list for new settlements. RPWK, nkl 1578, 1579, 1581, 1582.

${ }^{111}$ I. Gieysztorowa, "Źródła pisane," in: Mazowsze $w$ drugiej połowie XVI w., ed. W. Pałucki, Warszawa, 1973 (Atlas historyczny Polski. Mapy szczegółowe XVI w., vol. 7), p. 19.

112 This information was treated as the confirmation of the village's supposed inclusion into Poznań District in, for example, the Historical-Geographical Dictionary of Poznań Voivodeship in the Middle Ages [Słownik historyczno-geograficzny 
register contains 28 such "solvit Poznaniae" annotations, ${ }^{113}$ from which only four (Chociszewo, Rogoziniec, Lutol Wodny, Koźminek) could be included in Poznań District in the Historical Atlas of Poland. Another two, Kuślin and Łodzia, were tentatively included into the borders of Kościan District, ${ }^{114}$ while there was little doubt when it comes to the rest of this list, as most of the localities lay at a considerable distance from Poznań District (Godziszewo, Chobienice, Wojciechowo, Góra, Gaj, Zaborowo, Święcino, Dolsko, Księginki, Kunowo, Ostrów, Ostrowieczno Wielkie, Mszczyczyno, Grodnica, Siedlec, Krzekotowice, Pępowo Małe, Pępowo Wielkie, Oczkowice, Konary, Góreczka Żabia (Fig. 21-22).
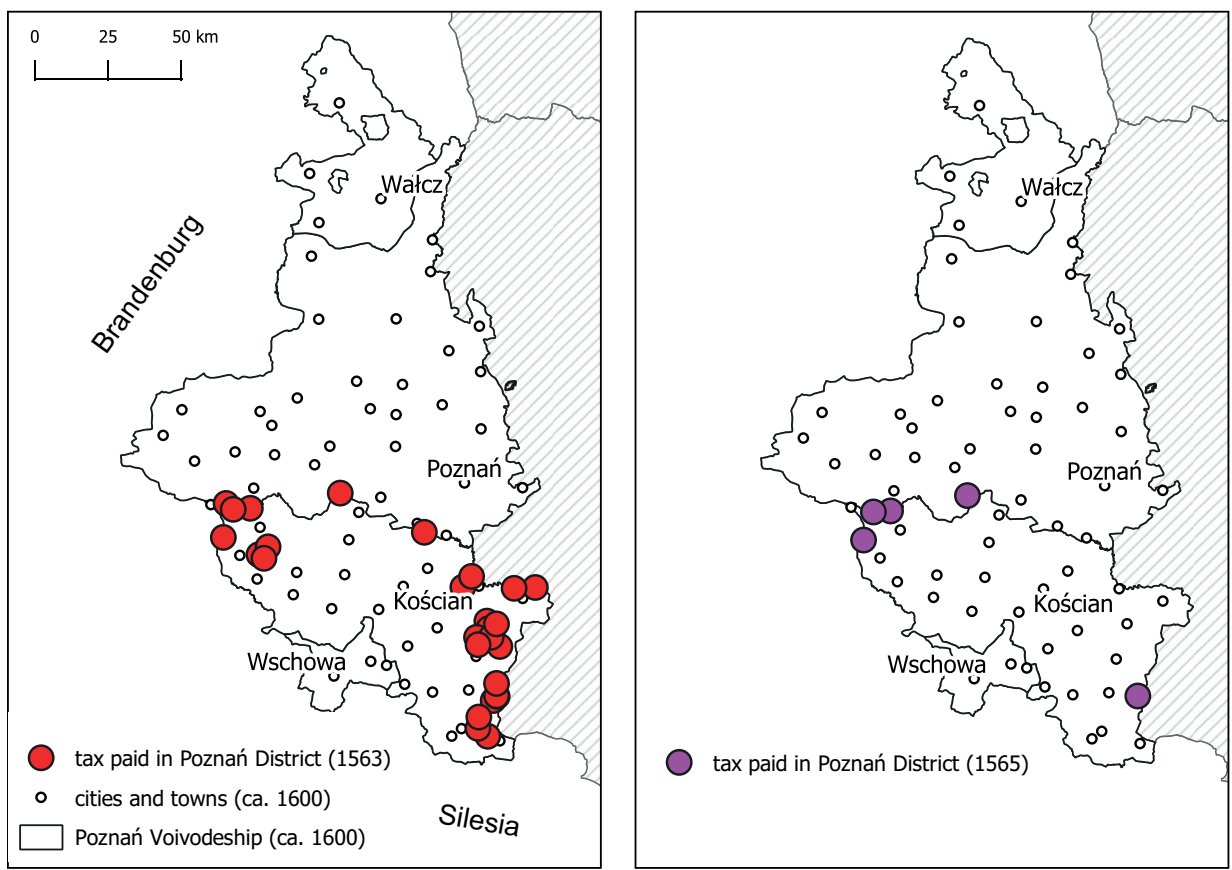

Fig. 21. Towns and villages listed in the 1563 and 1565 tax registers for Kościan District which had their taxes paid in Poznań

In the 1565 tax register from Kościan District, there are only five cases of tax being paid in Poznań (annotated "ad Poznaniam"), from

województwa poznańskiego w średniowieczu] in entries concerning Kuślin i Rogoziniec; T. Jurek, "Kuślin," in: Stownik historyczno-geograficzny województwa poznańskiego $w$ średniowieczu, part 2, p. 562; G. Rutkowska, "Rogoziniec," in: Stownik historyczno-geograficzny..., part 4, pp. 108, 111.

${ }^{113}$ RPWP, ksc, 1563, no. 9, 78, 81, 151, 154, 155, 163, 167, 180, 181, 183, 190, 226, 360, 380, 387, 429, 430, 431, 434, 528, 557, 593, 594, 595, 599, 672.

114 M. Gochna, "Podziały...," pp. 58-60. 
which one, Chociszewice, lay at a considerable distance from Poznań District. ${ }^{115}$

Another example was the village of Kuślin in Kościan District, perhaps providing a broader perspective on the topic, as some tax registers included information on village landowners as well as the dates of tax payment. The 1563 tax register from Kościan District notes that the tax for the Kuślin property was paid in Poznań. ${ }^{116}$ According to Kościan and Poznan tax registers from 1576, 1577, 1580, 1581, 1583, the landowner of Kuślin was Jan Strzeżmiński, ${ }^{117}$ who also paid taxes for villages located in Poznań District: Brody, Trzcianka, Krobielewo, Lubikowo, and Ninino (Fig. 22). On the $18^{\text {th }}$ of April 1580, Strzeżmiński paid tax for his properties in Kuślin, Lubikowo, and Brody. On the $20^{\text {th }}$ of April 1581, he made payments for Brody, Trzcianka, Kuślin, and Lubikowo, while on the $21^{\text {st }}$ of April he paid his tax on the land in Krobielewo, and on the $24^{\text {th }}$ of April - the leftover tax for Ninino.

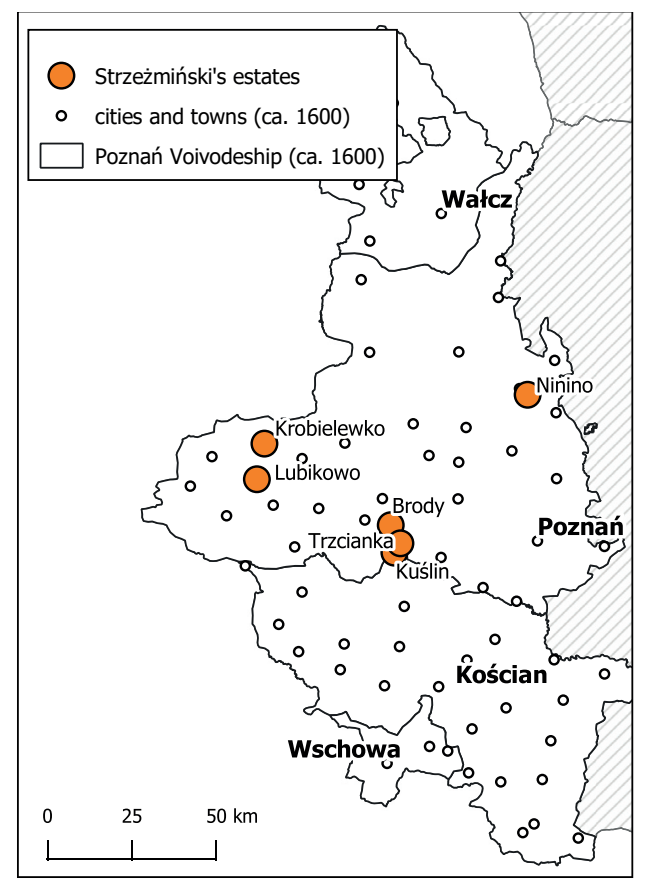

Fig. 22. Lands owned by Jan Strzeżmiński according to tax registers from the second half of the sixteenth century

115 RPWP, ksc, 1565, no. 149, 156, 157, 604, 663.

116 RPWP, ksc, 1563, no. 380.

117 RPWP, ksc, 1576 , no. 328 , 1577, no. 358 , pzn, 1580 , no. 361 , 1581, no. 359,1583 , no. 367 . 


\section{Conclusion}

As the introduction of taxes was a complex matter, our analysis focused only on several of the basic elements of the process. Firstly, we tried to establish the number and provenance of tax officials engaged in the collection of extraordinary taxes. It seems that the collectors who were responsible for accepting payments in particular districts and lands of the Crown were often people with connections to the king and were part of the royal political faction. However, in the sixteenth century, high social standing and public trust in local communities were the key factor in the selection of tax collector nominees.

Another matter was connected to the use of historical sources. We have concluded that further research is required in the study on draft and fair copies of the manuscripts of extraordinary tax registers. Our observations suggest that Treasury documentation compiled in local offices (municipal or starost courts) was being sent to the capital, Kraków, where it was organised and copied. A more in-depth study of the source materials gathered in the Crown's Treasury Archive might provide stronger conclusions on the subject.

The main difficulty in describing the extraordinary tax collection system in the Crown was the issue of the time period, as all examples in this article reflect the moment of a fundamental transition within the system. It can be said that while the sixteenth century was still a time when the revenue system was heavily centralised, towards the end of the sixteenth century these strong ties to the Crown Treasury began to gradually loosen. Tax collection and its supervision was slowly becoming the competence of the local diets, which were from then on not only responsible for selecting tax collectors and their personnel, but also oversaw bookkeeping and the management of the documentation on collections. ${ }^{118}$

Spatial mapping of tax collection is crucial in the analysis of the subject, which is best evidenced by the problem of locating villages in the administrative network of the Crown. Treasury documentation, in this case data from tax registers, can be entered into databases and, with the use of GIS software, can become the source of relatively quick geostatistical analyses; it also allows for comparison with other data available (environmental, archaeological, military). The logical next step is to postulate the expansion of computerised editions of sources pertaining

118 J. Rutkowski, Historia gospodarcza Polski (do 1864 r.), Warszawa, 1953, pp. 168-173. 
to the revenue system, like it was done in the case of tax registers from Greater Poland. ${ }^{119}$ It would greatly facilitate larger-scale research projects on various topics.

All of the aspects of our analyses - spatial, temporal, prosopographic, and relating to historical source studies - point to the need to expand our perspective on the issue of tax collecting. A thorough analysis would provide an insight into matters of administration, state, society, and economy in historical Poland. The data gained from such analyses could also be used as a basis of comparison for sources on modern fiscal systems in neighbouring countries.

Translated by Beata Lipinska

Acknowledgements

Research for this article was supported by the Polish National Programme for the Development of Humanities, no. 1aH15037383, and project of the National Scientific Centre no. 2017/27/L/HS3/03242. We would also like to thank Jolanta Choińska-Mika, Henryk Rutkowski, Adam Kozak and anonymous reviewers for their valuable suggestions.

\section{Bibliography}

Akta sejmikowe województw poznańskiego i kaliskiego, vol. 1: 1572-1632, part 1, 1572-1616, ed. W. Dworzaczek, Poznań 1957.

Augustyniak A., Historia Polski. 1572-1795, Warszawa, 2008.

Bielecka J., Inwentarze ksiag archiwów grodzkich i ziemskich Wielkopolski XIV-XVIII wieku: Województwo poznańskie, kaliskie, gnieźnieńskie, inowroctawskie, Poznań, 1965.

Bielecka J., "Kancelaria grodzka wielkopolska w XVI-XVIII wieku," St. Źródt. 1, 1957, pp. 120-155.

Bielecka J., "Organizacja i działalność kancelarii ziemskich i grodzkich wielkopolskich XIV-XVIII w.," Archeion 22, 1954, pp. 129-155.

Bielecka J., "Sąd grodzki w Wałczu," Roczniki Historyczne 26, 1960, pp. 265-271. Bieniaszewski A., "Urzędnicy wielkopolscy XVI-XVIII wieku. Spisy," in: Urzędnicy dawnej Rzeczypospolitej XII-XVIII wieku. Spisy, vol. 1, part 2, ed. A. Gąsiorowski, Wrocław, 1987.

Boroda K., "Kmieć, łan czy profit? Co było podstawa poboru łanowego w XV i XVI wieku?" in: Człowiek wobec miar i czasu w przeszłości, eds. P. Guzowski and M. Liedke, Kraków, 2007, pp. 152-170.

${ }^{119}$ RPWP; RPWK. 
Brzeczkowski T., "Ustanawianie podatków nadzwyczajnych w Polsce w XV w.," RDSG 42, 1981, pp. 77-105.

Chłapowski K., Realizacja reform egzekucji dóbr (1563-1665). Sprawa zastawów królewszczyzn małopolskich, Warszawa, 1984.

Chłapowski K., "Rejestry poborowe. Wstęp źródłoznawczy," in: Atlas Źródeł i Materiałów do Dziejów Dawnej Polski, 2015, part 2: Atlas historyczny Polski. Rejestry poborowe województwa kaliskiego w XVI w., ed. M. Słoń, http://atlasfontium.pl (10 X 2018).

Choińska-Mika J., Między społeczeństwem a władza. Problemy komunikacji społeczności lokalne - władza w epoce Jana Kazimierza, Warszawa, 2002.

Contamine Ph., War in the Middle Ages, Oxford, 1984.

The Court Account Book of Sigismund Jagiellon (1504-1507), eds. K. Rábai, R.R. Trimonienė and P. Kasza, Szedeg, 2014.

Filipczak-Kocur A., Skarbowość Rzeczypospolitej 1587-1648, Warszawa, 2006.

Gasiorowski A., Powiat w Wielkopolsce XIV-XVI wieku: z zagadnień zarzadu terytorialnego i podziałów Polski późnośredniowiecznej, Poznań, 1965.

Gasiorowski A., Urzędnicy zarządu lokalnego w późnośredniowiecznej Wielkopolsce, Poznań, 1970.

Gieysztorowa I., "Mazowieckie akta skarbowe XV-XVII w.: próba odtworzenia układu," in: Ksiega pamiatkowa 150-lecia Archiwum Głównego Akt Dawnych $w$ Warszawie, ed. A. Stebelski, Warszawa, 1958, pp. 209-217.

Gieysztorowa I., "Źródła pisane," in: Mazowsze w drugiej połowie XVI w., ed. W. Pałucki, Warszawa, 1973 (Atlas historyczny Polski. Mapy szczegótowe XVI w., 7), pp. 19-22.

Gochna M., "Elektroniczna edycja rejestrów poborowych województwa kaliskiego z drugiej połowy XVI w.," Studia Geohistorica 2, 2014, pp. 143-150.

Gochna M., "Podziały administracyjne. Granice państwowych jednostek terytorialnych," in: Wielkopolska w drugiej połowie XVI wieku, vol. 2, eds. K. Chłapowski and M. Słoń, Warszawa, 2017 (Atlas historyczny Polski. Mapy szczegótowe XVI w., vol. 4), pp. 46-64.

Gochna M., "Polish Nobility Seals in the 'recognitiones' of the Kalisz district in 1591. The perspective of an Edition," in: Editionswissenschaftliches Kolloquium 2015. Die Geschichte im Bild, eds. H. Flachenecker, K. Kopiński and J. Tandecki, Torun, 2016, s. 103-108.

Górska K., "Przyczynek do krytyki rejestrów poborowych z XVI wieku," St. Źródt. 1, 1957, pp. 185-189.

Guzowski P., Boroda K., "From King's Finance to Public Finance. Different Strategies of Fighting Financial Crisis in the Kingdom of Poland under Jagiellonian Rule (1386-1572)," in: La fiscalità nell'economia Europea secc. XIII-XVIII. Fiscal Systems in the European Economy from the $13^{\text {th }}$ to the $18^{\text {th }}$ Centuries, ed. S. Cavaciocchi, Firenze, 2016, pp. 451-470.

Herbst S., "Wojna moskiewska 1507-1508," in: Ksiega pamiatkowa ku czci Oskara Haleckiego wydana w 25-lecie jego pracy naukowej, Warszawa, 1935, pp. 29-54. 
Jurek T., "Kuślin," in: Stownik historyczno-geograficzny województwa poznańskiego $w$ średniowieczu, part 2, ed. S. Chmielewski et al., Wrocław, 1982, pp. 562-563.

Karwasińska J., "Archiwa skarbowe dawnej Rzeczypospolitej," in: Straty archiwów $i$ bibliotek warszawskich $w$ zakresie rękopiśmiennych źródet historycznych, vol. 1: Archiwum Gtówne Akt Dawnych, ed. A. Stebelski, Warszawa, 1956, pp. 70-125.

Kłodziński A., O Archiwum Skarbca Koronnego na Zamku Krakowskim, Kraków, 1923 (Archiwum Komisji Historycznej PAU, series 2/1).

Konopczyński W., Chronologia sejmów polskich 1493-1793, Kraków, 1948.

Listy $i$ akta Piotra Myszkowskiego, generalnego starosty ziem ruskich króla Jana Olbrachta zebrane przez śp. Adolfa Pawińskiego, ed. A. Lewicki, Kraków, 1898.

Matricularum Regni Poloniae summaria, vol. 4, ed. T. Wierzbowski, Warszawa 1917.

Myśliwski G., "From Feudal Rents towards a Tax System in Central Europe (the Thirteenth to the Fifteenth Century)," in: La fiscalità nell'economia Europea secc. XIII-XVIII. Fiscal Systems in the European Economy from the $13^{\text {th }}$ to the $18^{\text {th }}$ Centuries, ed. S. Cavaciocchi, Firenze, 2016, pp. 271-278.

Pawiński A., Skarbowość w Polsce i jej dzieje za Stefana Batorego, Warszawa, 1881.

Płaza S., Sejmiki i zjazdy szlacheckie województw poznańskiego i kaliskiego. Ustrój i funkcjonowanie (1572-1632), Warszawa-Kraków, 1994.

Polska w dobie odrodzenia. Państwo - spoteczeństwo - kultura, ed. A. Wyczański, Warszawa, 1970.

Pośpiech A., "Księgi rezygnacji w kaliskich aktach grodzkich z lat 1580-1655. Prezentacja źródła, możliwości badawcze," Rocznik Kaliski 21, 1989, pp. 19-49.

Registrum dvořanů knížete a krále Zikmunda I. Jagellonského z let 1493-1510: mezi periferii a centrem jagellonského světa, eds. P. Kozák and K. Rábai, Opava, [2015].

"Rejestry poborowe województwa kaliskiego w XVI wieku," vol. 2, ed. M. Słoń, Atlas Źródet i Materiałów z Dziejów Dawnej Polski, 2015, http://atlasfontium.pl (10 X 2018).

"Rejestry poborowe województwa poznańskiego w XVI wieku," vol. 3, ed. M. Słoń, Atlas Źródet i Materiałów z Dziejów Dawnej Polski, 2015, http:// atlasfontium.pl (10 X 2018).

Rutkowska G., "Rogoziniec," in: Stownik historyczno-geograficzny województwa poznańskiego $w$ średniowieczu, part 4, ed. S. Chmielewski et al., Wrocław, 1982, pp. 108-111.

Rutkowski H., "Cracow Voivodeship," in: Historical Atlas of Poland in the $2^{\text {nd }}$ Half of the $16^{\text {th }}$ Century. Voivodeships of Cracow, Sandomierz, Lublin, Sieradz, Łęczyca, Rawa, Płock and Mazovia, ed. M. Słoń, Frankfurt am Main, 2014, pp. 124-137. 
Rutkowski H., "Granice państwowych jednostek terytorialnych," in: Województwo krakowskie w drugiej połowie XVI wieku, ed. H. Rutkowski, Warszawa 2008 (Atlas historyczny Polski. Mapy szczegótowe XVI wieku, vol. 1), pp. 27-35.

Rutkowski J., Historia gospodarcza Polski (do 1864 r.), Warszawa, 1953.

Słoń M., "Digitale Edition der Ausheberregister aus der Wojewodschaft Kalisch des 16. Jahrhundert," in: Editionswissenschaftliches Kolloquium 2011. Quellen kirchlicher Provenienz neue Editionsvorhaben und aktuelle EDV-Projekte, eds. H. Flachenecker, J. Tandecki and K. Kopiński, Torun, 2011, pp. 393-405.

Słoń M., "Źródła pisane," in: Wielkopolska w drugiej połowie XVI wieku, vol. 2, eds. K. Chłapowski and M. Słoń, Warszawa, 2017 (Atlas historyczny Polski. Mapy szczegótowe XVI w., vol. 4), pp. 20-28.

Sucheni-Grabowska A., Odbudowa domeny królewskiej w Polsce 1504-1548, Warszawa, 2007.

Szulc T., "O dysponowaniu wpływami z podatków nadzwyczajnych w Polsce XV wieku," KH 99, 1992, fasc. 2, pp. 39-50.

Szulc T., "Przeznaczenie a wydatkowanie kwot z podatków nadzwyczajnych z dóbr szlacheckich w Polsce XV wieku," KH 100, 1993, fasc. 2, pp. 15-26.

Szulc T., "Sposoby wynagradzania poborców podatkowych w Polsce od schyłku XIV do XVIII wieku," Acta Universitatis Lodziensis. Folia Iuridica 56, 1993, pp. 91-106.

Uruszczak W., "Sejm koronacyjny w 1507 r. w Krakowie," Studia z Dziejów Państwa i Prawa Polskiego 7, 2002, pp. 111-121.

Urzędnicy wielkopolscy 1385-1500. Spisy, ed. A. Gąsiorowski, Poznań, 1968. Volumina Constitutionum, vol. 1, part 1, eds. S. Grodziski, I. Dwornicka, W. Uruszczak, Warszawa, 1996.

Volumina Constitutionum, vol. 2, part 1, eds. W. Uruszczak, S. Grodziski, I. Dwornicka, Warszawa, 2005.

Volumina Constitutionum, vol. 2, part 2, ed. S. Grodziski, Warszawa, 2008.

War and Economic Development. Essays in Memory of David Joslin, ed. J.M. Winter, Cambridge, 1975.

Wyczański A., Polska rzecza pospolita szlachecka: 1454-1764, Warszawa, 1965.

Michał Gochna, Tomasz Związek

Spatio-temporal aspects of the extraordinary tax collecting system in Greater Poland (1492-1613)

(Summary)

The article discusses several rarely-addressed issues in Polish historical literature related to spatial and temporal aspects of the extraordinary tax collection process in the Polish Crown from the end of the fifteenth to the beginning of the seventeenth century. The study focuses on demonstrating 
that through a comprehensive analysis of sources directly related to the collection mechanisms (tax registers, regestra retentorum), as well as normative acts introduced by the Sejm and the regional sejmik assemblies, it was possible to present various aspects of the functioning of tax collection in local spaces and outline the basic problems that arise in the analysis of those processes. One of the ways to spread news about the introduction of new taxes was the announcement of relevant documents by bailiffs in the most important municipal centres. Taxes were delivered directly to the district seats by noblemen, peasants, and community leaders. Handwriting analysis of early drafts has shown that tax registers preserved in the Central Archives of Historical Records in Warsaw require additional thorough source material studies, as they could potentially aid researchers in the identification of the clerical staff employed in the fiscal system, and make possible an attempt to answer the question of how long tax collection usually took. Such a comprehensive approach to the analysed material also contemplates the mechanisms of collecting outstanding taxes in both spatial and financial contexts. The authors indicate that research into the mechanisms of extraordinary tax collection does not only concern the revenue system, but also a wide array of social, economic, legal, state, and administrative issues.

Michał Gochna - mgr, doktorant i pracownik Zakładu Atlasu Historycznego w Instytucie Historii im. Tadeusza Manteuffla Polskiej Akademii Nauk. Jego zainteresowania badawcze obejmują historię skarbowości w okresie nowożytnym i geografię historyczna. Przeprowadza badania za pomocą metod i narzędzi humanistyki cyfrowej.

Michal Gochna - MA, PhD candidate and a member of the Department of Historical Atlas in the Tadeusz Manteuffel Institute of History, Polish Academy of Sciences. His research focuses on early modern fiscal studies and historical geography. He conducts his research using the methods and tools of Digital Humanities.

E-mail: mgochna@wp.pl.

Tomasz Związek - mgr, doktorant i pracownik Zakładu Atlasu Historycznego w Instytucie Historii im. Tadeusza Manteuffla Polskiej Akademii Nauk. Jego zainteresowania badawcze obejmuja geografię historyczną oraz historię średniowiecznej i nowożytnej kultury materialnej. Pisze pracę doktorską na temat zmian środowiskowych i krajobrazu osadnictwa wiejskiego w powiecie kaliskim na przełomie XV i XVI w. 
Tomasz Związek - MA, PhD candidate and a member of the Department of Historical Atlas in the Tadeusz Manteuffel Institute of History, Polish Academy of Sciences. His research areas include historical geography and history of the material culture of the Middle Ages and the early modern period. He is writing his thesis on the environmental changes and rural settlement landscape of Kalisz District at the turn of the $15^{\text {th }}$ and $16^{\text {th }}$ century.

E-mail: tomasz.zw@gmail.com. 